九州大学学術情報リポジトリ

Kyushu University Institutional Repository

\title{
A Systematic Study of the Japanese Pipunculidae (Diptera) : Part VI. The Genera Dorylomorpha Aczel and Tomosvaryella Aczel
}

Morakote, Rut

Entomological Laboratory, Faculty of Agriculture, Kyushu University

Hirashima, Yoshihiro

Entomological Laboratory, Faculty of Agriculture, Kyushu University

Yano, Koj i

Laboratory of Applied Entomology, Faculty of Agriculture, Yamaguchi University

https://doi.org/10.5109/23905

出版情報: 九州大学大学院農学研究院紀要. 34 (4)，pp.357-395，1990-03. Kyushu University バージョン：

権利関係 : 


\title{
A Systematic Study of the J apanese Pipunculidae (Diptera) Part VI. The Genera Dorylomorpha Aczél and Tomosvaryella Aczél*
}

\author{
Rut Morakote, Yoshihiro Hirashima and Kôji Yano** \\ Entomological Laboratory, Faculty of Agriculture, \\ Kyushu University, Fukuoka 812, Japan
}

(Received March 31, 1989)

\begin{abstract}
Twelve species of the genus Dorylomorpha Aczel and eight species of the genus Tomosvaryella Aczél from Japan are treated with key to species, descriptions and illustrations of important diagnostic characters. Six species of Dorylomorpha are new to Japan and five species are new species. Tomosvaryella caligata Hardy is newly recorded from Japan.
\end{abstract}

\section{Tribe TOMOSVARYELLINI}

Flies belonging to this tribe are characterized by having no coloration on the stigma. To date, only two genera are recorded in the world and both of them are found also in Japan.

\section{Genus DORYLOMORPHA Aczél}

Dorylomorpha Aczel, 1939, Zool. Anz. 125 : 22 (as subgenus of Tomosvaryella Aczél, 1939). Type species :Pipunculus rufipes Meigen, 1824, Syst. Beschr., 4 : 21, by monotypy.

Flies of this genus are separated from the genus Tomosvaryella Aczel by having the $\mathrm{r}-\mathrm{m}$ cross vein of coloration on the $\mathrm{r}-\mathrm{m}$ cross vein of wings situated near the base of the discal medial cell (about the basal sixth to fourth). Up to date, about 40 species have been recorded to science. Host records of this genus have been reported by many authors (Perkins, 1905 ; Williams, 1919 ; Waloff, 1975 and 1980 ; Chu and Hirashima, 1981) which reveals that most of them parasitize the homopterous insects of the family Cicadellidae and Delphacidae.

In Japan, only D. Zini Hardy was recorded for the first time by Yano et al. in 1984. This paper presents eleven more species including five new species and four species new to Japan.

*Contribution from the Entomological Laboratory, Faculty of Agriculture, Kyushu University, Fukuoka (Ser. 3, No. 306)

**Laboratory of Applied Entomology, Faculty of Agriculture, Yamaguchi University, Yamaguchi 753, Japan 
Key to males of Japanese species of DORYLOMORPHA

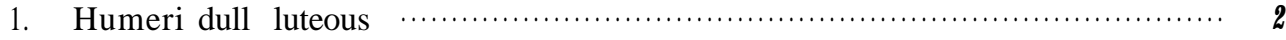

Humeri dull black ............................................................... 3

2. Legs entirely yellow; abdominal segments extensively yellow with some black markings; tergite 8 with membranous area on the right side of apex ; genitalia as shown in Fig. $111 \mathrm{~A}-\mathrm{F}$

....D. yamagishii Morakote et Yano, sp. n.

- Legs mainly black ; abdominal segments entirely black ; tergite 8

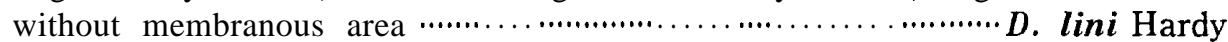

3. Tergite 8 without membranous area, abdominal terminalia remarkably enlarged ; third antennal segment brownish black, short acuminate ; genitalia (Fig. 110A-D) with large asymmetrical surstyli

D. haemorrhoidalis (Zetterstedt)

- Tergite 8 with membranous area

4. Tergite 8 with a depression (not membranous) behind ; third antennal segment rostrate; genitalia with symmetrical surstyli ; surstylus (Fig. $115 \mathrm{H})$ with constricted base and very enlarged posterior margin

D. rectitermina Morakote et Yano, sp. n.

- Tergite 8 without a depression

5. Trochanters yellowish brown ; third antennal segment rostrate ; genitalia (Fig. 114A-E) with symmetrical surstyli ….......... D. imparatu (Collin)

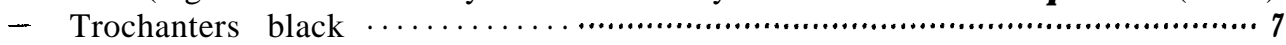

6. Tergite 8 very long, about as long as tergite 5 when viewed from above (Fig. 112D) ; femora black except extreme base and tip ; surstylus as shown in Fig. 115G ....................................... D. spinosa Albrecht

- Tergite 8 shorter than tergite 5, generally about half as long as $\ldots \ldots \ldots \ldots \ldots \ldots . \ldots$

7. Surstylus with a small beak-like process on inner-side margin (Fig. 115I and $\mathrm{K}$ )

- Surstylus without a small beak-like process on inner-side margin (Fig. 115J) .......................................................... D

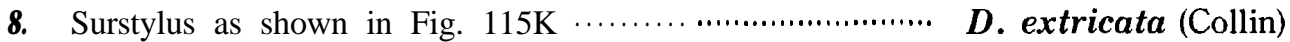

- Surstylus as shown in Fig. 1151 ‥ D. kurodakensis Morakote et Yano, sp. n.

Key to known females of Japanese species of DORYLOMORPHA

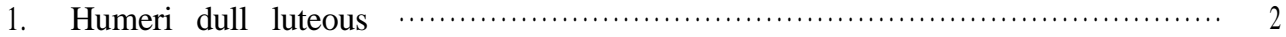

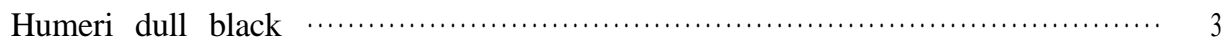

2. Legs entirely yellow; abdominal tergites extensively yellow, with some black markings ; ovipositor entirely yellow (Fig. 115E)

D. yamagishii Morakote et Yano, sp. $\mathrm{n}$.

- Legs mainly black ; abdominal segment entirely black ; ovipositor rather short ; with subglobular black base ; piercer about as long as base, almost straight

D. lini Hardy

3. Abdominal tergites 3 and 4 extensively yellow, but still with black marking on dorsum ; third antennal segment short acuminate (Fig. 
113D) ; legs entirely yellow ; ovipositor as shown in Fig. 113B and C

D. yanoi Morakote, sp. n.

- All abdominal tergites entirely shining black

4. Third antennal segment short acuminate; femora black except extreme tip yellow ; ovipositor (Fig. 109E) remarkably large, entirely yellow ; base flattened ; piercer thick at basal part, about as long as

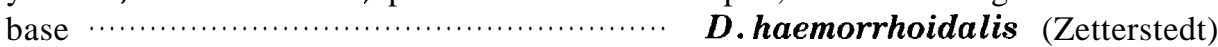

- Third antennal segment long rostrate

5. Trochanters yellowish brown ; ovipositor (Fig. 107F) with base oval,

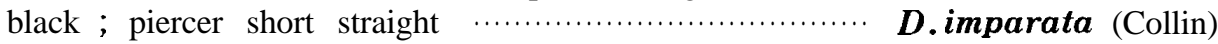

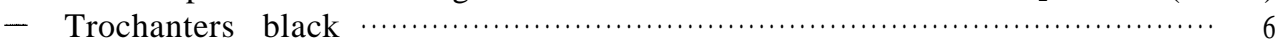

6. Femora almost entirely black except extreme one-seventh of base and

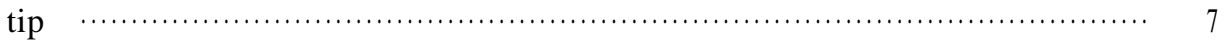

- Femora mainly black, with posterior one-third to one-fourth yellowish $\ldots \ldots \ldots 8$

7. Ovipositor (Fig. 113A), base small, oval, entirely black ; piercer long, slender, about twice as long as base …................... D.rufipes (Meigen)

- Ovipositor with base piercer large and stout (Fig. 113E) ; base oval, entirely black ; piercer about 1.5 times as long as base, thick at basal part in lateral view, apical half aculeous, almost straight

D. valida Morakote et Yano, sp. n.

8. Ovipositor (Fig. $105 \mathrm{~A}-\mathrm{C}$ ) with rather long piercer but less than twice as long as base ; piercer slightly upcurved D. confusa (Verrall)

- Ovipositor with piercer shorter than that of confusa; piercer quite thick at base and piercer in ventral view (Fig. 108E) ….. D. extricata (Collin)

\section{Dorylomorpha confusa (Verrall)}

Pipunculus confusus Verrall, 1901, Brit. Flies, 8 : 114. - Collin ; 1937, Ent. mon. Mag., $73: 215$.

Dorylomorpha confusa, Coe, 1966, Handbk. Ident. Brit. Ins., 10 (2C) : 43, 47. Lauterer, 1981, Acta Mus. morav. (Sci. nat.), $66: 127$.

Male (Figs. 104 and 115J).

Head (Fig. 105D) : Eyes widely separated ; frons slightly convex and narrowest at middle, with a shining median black ridge, upper half shining black, lower half cinereous ; occiput enlarged, widest on upper part, about one-fifth as long as head, black, with greyish dust. Antenna (Fig. 105G) with first and second segments small, brownish black, quite bare ; third segment long rostrate, about three times as deep as the second, brownish, tinged with yellow anteriorly.

Thorax and scutellum shining black, with obscurely brownish dusting, quite bare but with differentiated rows of short hairs on each dorsocentral line; scutellum with faintly short fine marginal hairs; humeri black.

Legs with coxae and trochanters black, femora mainly black except posterior one-third to one-fourth brownish, tibiae and tarsi yellowish except last tarsal segment brownish black anteriorly, pulvilli yellowish, slightly shorter than last tarsal segment, mid femora with two parallel rows of small black spines beneath, tibiae with yellow 
posteroapical spur ; last tarsal segment with three long black bristles anteroapically.

Wings rather clear, third costal section uncolored, short, about one-fourth as long as fourth, r-m situated about basal one-fifth of discal medial cell ; last section of vein $\mathrm{Ml}$, undulating, halteres and calypteres yellow.

Abdomen subshining black, densely covered with short pale hairs and sparsely longer pale hairs over all tergites, abdominal segments gradually enlarged from segment 1 to segment 5 , tergite 1 shortest, with a fan of long pale hairs anterolaterally ; tergite 5 longest ; tergite 8 enlarged, but rather short, about half as long as tergite 5, triangular shape with apex pointed to the right when viewed from above.

Genitalia with symmetrical surstyli, surstylus different from those of other species as shown in Fig. 104D.

Length : Body $5 \mathrm{~mm}$; wing $5.2 \mathrm{~mm}$.

\section{Female.}

Differring from the male as follows : Frons wider than in male ; middle of frons more convex with larger black ridge ; eyes with front ommatidia moderately enlarged. Ovipositor (Fig. 105A-C); base roughly oval, less convex behind, basal half brownish black, remainder brownish; piercer slightly upcurved, quite long, brownish; joint between base and piercer noticeably convex below.

Length : Body $5 \mathrm{~mm}$; wing $5.2 \mathrm{~mm}$.

Specimens examined. (Honshu) 1 mating pair, Yokomuki, Mt. Adata, Fukushima Pref., 10. vii. $1985: 6 \sigma^{7} \sigma^{x}$, same data; $26 \sigma^{x} 2$ 우우, Kawaranobo, Mt. Hayachine, Iwate Pref., 16. vii. 1985 ; 26 주1 우 Hosono, Mt. Okubandai, Fukushima Pref., 9. vii. 1985 ;1 ๑7, Goshikinuma, Urabandai, Fukushima Pref., 20. vii. 1985 ;1우, Arakawa, Sanpukumachi, Niigata Pref., 5. vii. 1985 ; all were collected by R. Morakote ; $1 \sigma^{7}$, Mt. Hayachine, Iwate Pref., 11-12. vi. 1980 (M. Suwa) ; 16, Mt. Ustukushigahara, 3. vii. 1965 (T. Okadome) ; (Hokkaido) 36 ㄲ3우우 Nukabira, Kamishihoro, Tokachi, 28. vi. $1986 ; 4 \sigma^{7} \sigma^{\top}$, Raus Onsen, Nemuro, 8. vii. $1986 ; 3 \sigma^{77} \sigma^{71} 1$ 우, Akankohan, Mt. 0-akan, Kushiro, 4. vii. $1986 ; 1 \sigma^{7}$, Shojikawa, Raus, Nemuro, 9. vii. 1986 ; 26 శ , Shunbetsu, Nemuro, 5. vii. 1986 ; 3 ఠ , Sounkyo, Mts. Daisetsuzan, Kamikawa, 26. vi. 1986, all

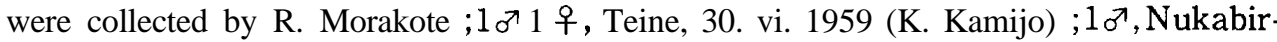
a, 13. vii. 1959 (T. Kumata).

Host : Unknown.

Distribution : Japan (Hokkaido, Honshu), Europe.

Remarks: This is the first record of this species from Japan.

\section{Dorylomorpha impara ta (Collin)}

Pipunculusimparatus Collin, 1937, Ent. mon. Mag., 73 : 216.

Dorylomorpha imparata : Coe, 1966, Handbk. Ident. Brit. Ins., 10 (2C) : 43, 47. Lauterer, 1981, Acta Mus. morav. (Sci. nat.), $66: 137$.

M ale (Figs. 107A-D).

Differing from the male of D. confusa as follows: Trochanters yellowish brown, tergite 8 with apex rather rounded when viewed from above, apex pointed directly ; genitalia (Fig. 114A-E) with symmetrical surstyli ; surstylus clearly different from 
that of $D$. confusa as shown in Fig. 107D.

Length : Body $5 \mathrm{~mm}$; wing $5.4 \mathrm{~mm}$.

\section{Female.}

Differing from the female of D.confusa as follows : trochanters yellowish brown ; ovipositor (Fig. 107F) moderately large ; base oval, entirely blackish ; piercer rather short, only slightly longer than base, dark brown, no sign of constriction between base and piercer when viewed from above.

Length : Body $5 \mathrm{~mm}$; wing $5.3 \mathrm{~mm}$.

Specimens examined : (Hokkaido) 1 mating pair, Raus Onsen, Nemuro, 8. vii. 1986 ;

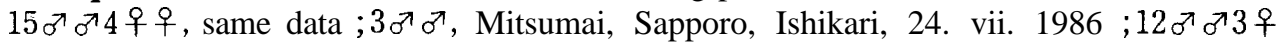
우, Sounkyo, Mts. Daisetsuzan, Kamikawa, 11. vii. $1986 ; 8 \sigma^{7} \sigma^{7}$, Akan kohan, Mt.

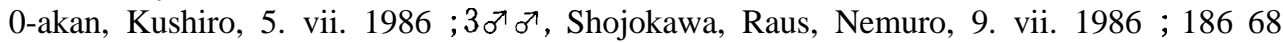
우우, Nukabira, Kamishihoro, Tokachi, 29. vi. $1986 ; 2 \sigma^{7} \sigma^{7}$, Kamishibetsu, Nemuro, 9. vii. 1986 ; 16, Saroma, Abashiri, 10. vii. 1986 ; all were collected by R. Morakote ;1 Ashoro, Tokachi, 11. vi. 1985 (M. Abe) ; 26 万 , Hokkaido, no date (Matsumura coll.); $10^{7}$, Shirataki, Kitami, 16. vi. 1974 (T. Kumata et al.) : 1 우, Jozankei, 26. v. 1968 (K.

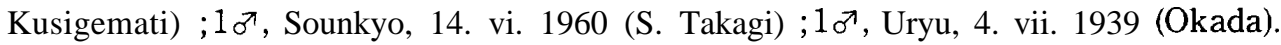
(Honshu) $10^{7}$, Uradanai, Kitashitara, Aichi Pref., 16. v. 1971 (S. Ohkusa) ;1 $\sigma^{7}$, same locality (K. Yamagishi) ; 16, Utsukusigahara, 4. vii. 1965 (T. Kunou) ;1 $\sigma^{\text {శ }, ~ N i k k o, ~} 3$. vi. 1911 (Matsumura).

Host : Unknown.

Distribution: Japan (Hokkaido, Honshu), Europe.

Remarks: This is the first record of this species from Japan.

\section{Dorylomorpha extricata (Collin)}

Pipunculus extricatus Collin, 1937, Ent. mon. Mag., $73: 218$.

Dorylomorpha extricata : Coe, 1966, Handbk. Ident. Brit. Ins., 10(2C): 43, 47. -

Lauterer, Acta Mus. morav. (Sci. nat.), $66: 135$.

M ale (Fig. 108A-D).

Differing from the male of D. confusa as follows : Abdominal tergite 8 larger, with apex compressed to the right but not roughly triangular shape as confusa. Genitalia with symmetrical surstyli, surstylus (Fig. 115K) almost similar to that of confusa but having a beak-like process on posterior of inner-side margin.

Length : Body $5 \mathrm{~mm}$; wing $5.5 \mathrm{~mm}$.

F emale (Fig. 108E-G).

Differing from the female of $D$. confusa as follows : Ovipositor (Fig. 108E and F) rather stout ; base oval, more convex behind, entirely blackish ; piercer almost straight, quite thick, slightly longer than base, dark brown; between base and piercer constricted when viewed from above (Fig. 108E).

Length : Body $5 \mathrm{~mm}$; wing $5.5 \mathrm{~mm}$.

Specimens examined. (Kyushu), $4 \sigma^{7} \sigma^{77} 7$ 우우, Mt. Hikosan. Fukuoka Pref., 7-9. v. 1986 (R. Morakote) ;1우, same locality, 25. iv. 1985 (M. Abe) ;3 $\sigma^{\nearrow} \sigma^{\nearrow}$, same locality, 23. 
iv. 1969 (Hikosan Biol. Lab. Coll.).

Host : Unknown.

Distribution : Japan (Kyushu), Europe.

Remarks : This is the first record of this species from Japan.

\section{Dorylomorpha haemorrhoidalis (Zetterstedt)}

Dorylas huemorrhoidalis Zetterstedt, 1838, Insecta Lapp., Dipt., 580.

Pipunculus haemorrhoidalis, Zetterstedt, 1844, Dipt. Scand., 3 : 959. — Becker, 1897,

Berlin. ent. Zschr., $152: 91$; — 1900, Berl. ent. z., $45: 236,240 .-$ Verrall,

1901, Brit. Flies, $8: 116 . \quad$ Collin, 1937. Ent. mon. Mag., $73: 214$.

Tomosvaryella (Dorylomorpha) huemorrhoidalis : Aczél, 1939, 2001. Anz., $125: 53$.

Dorylomorpha huemorrhoidalis : Coe, 1966, Handbk. Ident. Brit. Ins., 10(2C): 42.

Pipunculus albilarsis Zetterstedt : 1844, Dipt. Scand., 3 : 958.

Male (Figs. 109A-D and 110).

Head : Eyes widely separated ; frons narrowest and slightly convex at middle, with a black ridge, upper half shining black, lower half cinereous ; antennae (Fig. 109F) with first and second segments brownish black, third segment dark brown, short acuminate ; occiput enlarged, widest on upper part, about one-fourth as long as head.

Thorax and scutellum as that of D. confusa.

Legs with coxae, trochanters and femora black except extreme base and tip of femora brownish.

Wings rather clear, third costal section about one-fifth of discal medial cell, last section of vein $\mathrm{Ml}$ as long as fourth costal section.

Abdomen (Fig. 109A-D) subshining black, densely covered with short pale hairs and sparsely longer pale pubescence ; abdominal terminalia remarkably enlarged, tergite 8 with roughly oval large membranous area behind, slightly shorter than tergite 5 when viewed from above, tergite 7 expanded over left surstylus.

Genitalia (Fig. 110A-D) noticeably large, with asymmetrical surstyli, right surstylus considerably larger than the left, basal inner-side of surstyli with numerous short hairs.

Length : Wing $4.5 \mathrm{~mm}$.

\section{Female.}

Almost resembling the male but differing as follows : Frons wider, about as wide as ocellar triangle, upper half shining black, lower half cinereous. Ovipositor (Fig. $109 \mathrm{E})$ remarkably enlarged, rather flattened, brownish yellow; base of ovipositor larger than piercer, about twice as long as piercer short, very thick at basal part as seen from ventral, then suddenly slender from middle to apical tip.

Specimens examined :10, Sapporo, Hokkaido, 24. vii. 1959 (S. Takagi) ;1 우, same locality and collector, 9. v. 1959.

H ost : Unknown from Japan ; in England Cicadulaquadinotata (F.) (Hemiptera : Cicadellidae)(see Waloff, 1980).

Distribution: Japan (Hokkaido), Europe.

Remarks: This is the first record of this species from Japan. This species is easily 
distinguished from other species by the very large abdominal terminalia in both sexes,

\section{Dorylomorpha rufipes (Meigen)}

Pipunculus rufipes Meigen, 1824, System. Beschreib., $4: 21$. Files, $8: 115$. C Collin., 1937, Ent. mon. Mag., $73: 217$

Tomosvaryella (Dorylomorpha) rufipes rufipes: Aczél, 1939, 2001. Anz. $125: 63$.

Dorylomorpha rufipes : Coe, 1966, Handbk. Ident. Brit. Ins., 10 (2C) : 47. — Lauterer, 1981, Acta. Mus. morav. (Sci. nat.), $66: 140$.

F emale (Fig. 113A).

Very resembling the female of D. confusa but differing as follows : Smaller ; femora almost entirely black ; except extreme tip brownish ; tibiae yellowish, darkened about middle ; ovipositor (Fig. 113A) moderately large ; piercer very long and slender, about twice as long as base, apical tip extending black beyond posterior margin of sternite 3 , straight, dark brown.

Length : Body $3.8 \mathrm{~mm}$; wing $3.8 \mathrm{~mm}$.

Specimen examined. 1 우, Shunbetsu, Nemuro, Hokkaido, 5. vii. 1986 (R. Morakote).

Host : Unknowm from Japan ; in England as Cicadula quadinotata (F.) (Hemiptera : Cicadellidae) (see Waloff, 1975).

Distribution : Japan (Hokkaido), Europe.

Remarks : This is the first record of this species from Japan.

\section{Dorylomorpha spinosa Albrecht}

Dorylomorpha spinosa Albrecht, 1979, Entomologica scand.,10(3): 211.

M ale (Fig. 112A-D).

Differing from the male of D. confusa as follows : Antenna with third segment darker than that of confusa; legs with femora almost entirely black except extreme tip brownish, tibiae darkened posteromedially ; tarsi yellowish but darkened anteriorly. Wings with third costal section about one-third as long as fourth, r-m situated about one-fourth of discal medial cell. Abdominal tergite 8 very long, about as long as tergite 5 when viewed from above. Genitalia rather large, surstyli symmetrical ; surstylus (Fig. 115G) large, with small beak-like process on inner-side subapically.

Length : Body $4.8 \mathrm{~mm}$; wing $5 \mathrm{~mm}$.

Specimens examined. (Hokkaido) 107, Akankohan, Mt. 0-akan, Kushiro, 4. vii. 1986 (R. Morakote) ; 16, Shunbetsu, Nemuro, 6. vii. 1986 (R. Marakote), ;1 $\sigma^{7}$, Shibecha,

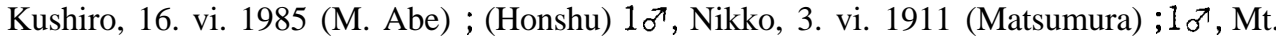
Mito, Tokyo, 27. v. 1967 (H. Takizawa) ;1 $1 \sigma^{\nearrow}$, Mt. Kasa, Saitama, 26. v. 1967 (H. Takizawa).

Host : Unknown.

Distribution : Japan (Hokkaido, Honshu), Europe.

Remarks : This is the first record of this species from Japan. This species is dis inguished from other species of the genus by having the very long eighth abdominal tergite which is about as long as the tergite 5 when viewed from above. 
Dorylomorpha yamagishii Morakote et Yano, sp. n.

M ale (Fig. 111).

Head : Eyes widely separated, frons narrowest on upper half then gradually widened to base of antennae, upper half shining black, lower half cinereous ; antenna with first and second segments brownish black, third segment yellowish, short acuminate, about twice as deep as the second ; occiput black, with grey dust, widest on upper part, about one-fourth as long as head.

Thorax and scutellum quite bare, shining black; humeri dull luteous, pleurae black, greyish pruinose.

Wings clear, third costal section about one-fourth as long as fourth, r-m situated about one-fifth to one-sixth of discal medial cell; last section of vein Ml almost straight.

Legs entirely yellow.

Abdomen brownish black, with yellow markings on tergites 1-4 as shown in Fig. $115 \mathrm{~A}$, with densely short pale hairs and sparsely longer pale pubescence on all tergites ; tergite 5 longest when viewed from above ; tergite 7 expanded over left surstylus ; tergite 8 slightly shorter than tergite 5 , with moderately large oval shape membranous area at the right side of apex.

Genitalia (Fig. 111A-F) with asymmetrical surstyli ; surstyli narrow and long, left surstylus moderately larger than the right, folded apically.

Length : Body $3.2 \mathrm{~mm}$; wing $3.2 \mathrm{~mm}$.

\section{Female.}

Differing from the male as follows : Frons wider than in male, almost as wide as ocellar triangle, with parallel side margins, each side margin with a row of short pale hairs running down from vertex to middle of frons. Abdomen extensively yellow, with black markings on tergites 2-6 dorsally (Fig. 115E). Ovipositor entirely on yellowish, base flattened, about as long as piercer, with shallow depression dorso-medially ; piercer with basal part thickened as seen from side but apical part short acuminate.

Length : Body $3.2 \mathrm{~mm}$; wing $3.2 \mathrm{~mm}$.

Holotype: $\sigma^{7}$, Nisshin-cho, Aichi Pref. 9. v. 1971 (K. Yamagishi), in the collection of Meijo University.

Paratypes: $2 \sigma^{7}^{7} 3$ 우우, same data as holotype.

Host : Unknown.

Distribution: Japan (Honshu).

Remarks : This species is rather small compared with other Japanese members of Dorylomorpha. It is very similar to the European species $D$. maculata but differs by the lack of yellow bristles at the middle of the hind tibiae.

\section{Dorylomorpha rectitermina Morakote et Yano, sp. $n$.}

M ale (Fig. 112E-H).

Very resembling the male of $D$. confusa but differing as follows : Abdominal tergite 8 with a depression (not membranous area) on apex which is clearly seen only from behind, rather short and with posterior margin straight when viewed from above 
(Fig. 112G); genitalia with symmetrical surstyli, each surstylus (Fig. 115H) enlarged on posterior portion and constricted at base.

Length : Wing $5.2 \mathrm{~mm}$.

Holotype: 万ٓ (Type No. 2765, Kyushu Univ.), Yokomuki, Mt. Adatara, Fukushima Pref., 9. vii. 1985 (R. Morakote).

Host : Unknown.

Distribution : Japan (Honshu).

Remarks : This species is distinguished from other species of the genus by having the depression on the tergite 8 devoid of membranous area.

Dorylomorpha kurodakensis Morakote et Yano, sp. n.

M ale (Fig. 107G-J and 1151).

This species is closely similar to the male of D. confusa but the genital surstyli is decidedly different in profile as shown in Fig. 1151.

Length : Body $4.8 \mathrm{~mm}$; wing $5.3 \mathrm{~mm}$.

Holotype: $\sigma^{7}$ (Type No. 2766, Kyushu Univ. ), Mt. Kurodake, Oita Pref., Kyushu, 29 iv. 1985 (R. Morakote).

Paratypes: $3 \sigma^{\nearrow}$, same locality and collector, 27. vi. 1985.

Host : Unknown.

Distribution: Japan (Kyushu).

Dorylomorpha valida Morakote et Yano, sp. n.

Female (Fig. 113E).

Almost resembling female of $D$. confusa but differing as follows : Legs with femora almost entirely black except extreme tip yellow ; tibiae yellow but darkened posteromedially. Abdomen rather stout (Fig. 113E); ovipositor large ; base oval, entirely black, piercer about 1.5 times as long as base, enlarged at basal part, apical half aculeous, almost straight, apex extending back to posterior margin of tergite 2 . Length : Body $4.2 \mathrm{~mm}$; wing $4.7 \mathrm{~mm}$.

Holotype:우 (Type No. 2767, Kyushu Univ.), Akankohan, Mt. 0-akan, Kushiro, Hokkaido, 3. vii. 1986 (R. Morakote).

Distribution : Japan (Hokkaido).

Host : Unknown.

\section{Dorylomorpha yanoi Morakote, sp. n.}

Female (Fig. 113B and C).

Head : Eyes widely separated ; frons with lateral margin parallel, each lateral margin with a row of short pale hairs running down from vertex to middle of frons, upper half shining black triangular shape, remainder cinereous ; antenna (Fig. 113D) with first and second segments dull black, third segment yellowish brown, short acuminate, about two times as deep as the second ; occiput cinereous, widest on upper part, about one-third to one-fourth as long as head.

Thorax and scutellum quite bare, subshining black, humeri darkened ; pleurae 
mainly darkened.

Wings clear ; third costal section about one-fifth as long as fourth, r-m situated about one-fifth of discal cell ; last section of fourth vein Ml slightly undulating.

Legs entirely yellow; tibiae with a yellow posteroapical spur.

Abdomen (Fig. 113B) mainly subshining black except tergites 3 and 4 with extensively yellow markings at sides, densely covered with short pale hairs and longer pale pubescence over all tergites, tergite 1 with a fan of some long pale pubescence anterolaterally.

Ovipositor (Fig. 113B and C) entirely dull yellow ; base flattened, with moderately deep depression at middle ; piercer as long as base, thickened at base as seen from side, short acuminate apically, fountain-pen shape when viewed from above as shown in Fig. $113 \mathrm{c}$.

Length : Body $3.5 \mathrm{~mm}$; wing $4.5 \mathrm{~mm}$.

Holotype:우 (Type No. 2768, Kyushu Univ.), Akankohan, Mt. 0-akan, Kushiro, Hokkaido, 3. vii. 1986, (R. Morakote).

Paratype: 우, Sapporo, 24. vii. 1959 (S. Takagi).

Host : Unknown.

Distribution: Japan (Hokkaido).

Remarks : This species much resembles the female of D. yamagishii by having the entirely yellow legs and the yellow markings on the abdomen but differs as follows : larger ; humeri black; yellow markings on abdomen rather restricted on tergites 3 and 4 ; ovipositor clearly different in profile.

\section{Dorylomorpha lini Hardy}

Dorylomorpha lini Hardy, 1972, Proc. Haw. ent. Soc., $21: 81$. — Yano, 1979, Esakia, $13: 48$. — Yano et al., 1984, Trans. Shikoku ent. Soc., 16 (4) : 70.

\section{Host : Unknown.}

Distribution : Japan (Okinawa), Taiwan, Philippines, Thailand.

Remarks : This species is found in paddy fields. It seems to be very rare in Japan, for only three specimens have been recorded by Yano et al. (1984), although many works have been carried out on pipunculids dwelling in paddy fields until now.

\section{Genus TOMOSVARYELLA Aczél}

Tomosvaryella Aczél, 1939, 2001. Anz., 125 : 22. Type species : Pipunculus sylvaticus Meigen, 1824, by original designation.

Alloneura Rondani, 1856, Dipt. Ital. Prodromus., 1 : 140. Suppressed by I. C. Z. N., Bull. zool. nom., 1961, 18(4): 230, Opinion 597.

This genus is separated from the genus Dorylomorpha Aczél by the following characters : The eyes holoptic in male ; the abdomen in both sexes generally widest at the junction of segments 3 and 4 ; the abdominal terminalia usually not larger than segment 5 ; the $r-m$ cross vein of wing situated near middle of discal median cell.

Flies of this genus in Japan are mostly found in paddy fields. Koizumi (1959) firstly 
described T.oryzaetora Koizumi as the parasite of the green rice leafhopper Nephotettix cinticeps (Uhler) and subsequently in 1960 he reported four more species (T.inazumae (Koizumi), T. itoi (Koizumi), T.coquiletti (Kertész) and T. sylvatica (Meigen)). He suggested that T.inazumae parasitizes the zigzag-stripe leafhopper, Recilia dorsalis (Motschulsky), T. itoi may have some relations to Psammotettix striatus (Linnaeus), and $T$. sylvatica is the parasite of N.cincticeps. Recently, Yano et al. listed 6 species of this genus inhabiting paddy fields in Japan, in which two more species T.subvirescens (Loew) and 7'. epichalca (Perkins) were newly added.

At present, we found one more species, by which raised the record numbers of this genus in Japan became eight.

Key to known Japanese species of genus TOMOSVARYELLA

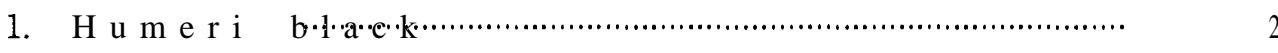

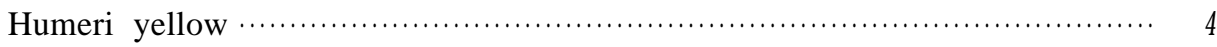

2. Abdominal tergites subshining black, conspicuous greyish pruinose ; abdominal tergite 8 about one-third as long as tergite 5 ; abdominal sternite bare ; epandrium small, as wide as long; surstyli asymmetrical, about as long as epandrium (Fig. 119B), female ovipositor as shown in Fig. $120 B$

T. oryzaetora Koizumi

Abdominal tergites metallic black ; abdominal tergite 8 about one half as long as tergite 5 ; abdominal sternites 3-5 with a band of minute spines on each side near posterior margin ; epandrium rather large ; surstyli as shown in Fig. 120D ; female ovipositor as shown in Fig.

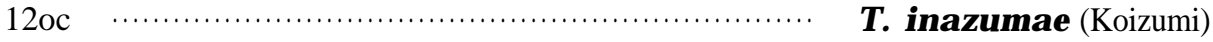

3. Hind femora with outstanding posteroventral cilia of delicate pale hairs ; tarsi black ; hind trochanters without short spines beneath ; male genitalia with broad and triangular surstyli (see original description by Koizumi, 1960) …................................ T. Toi (Koizumi)

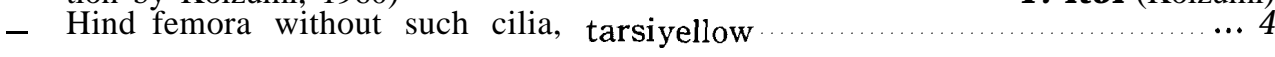

4. Abdominal terminalia (tergite 8) symmetrical, rounded posteriorly as

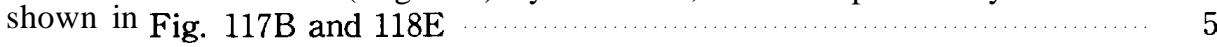

- Abdominal terminalia (tergite) asymmetrical …............................. 6

5. Hind trochanter flatted beneath (Fig. 118F) ; tergite 8 about one half as long as tergite 5 , with large membranous area on the right side which clearly seen from above ; epandrium (Fig. 119A) very much swollen ; surstyli short, asymmetrical …....................... T. subvirescens (Loew) Hind trochanters simple; tergite 8 with membranous area on apex which is scarcely seen from above ; surstyli (Fig. 117C) symmetrical,

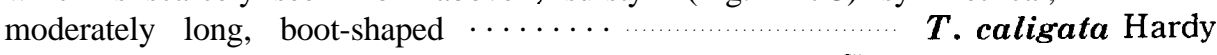

6. Epandrium with longitudinal median groove (Fig. 119C); abdominal tergites metallic black; tergite 8 (Fig. 118D) roughly perpendicular

Epandrium without longitudinal median groove

T. coquiletti (Kertész)

7. Hind trochanters with a group of conspicuous 5-6 black spines beneath ; metallic black species ; abdominal tergite 8 (Fig. 118C) roughly tri- 
angular shape, with large membranous area on apex ; epandrium and surstyli rather large as shown in Fig. 119D …............. T. sylvatica (Meigen)

- Hind trochanters bare ; metallic black species ; abdominal tergite 8 not triangular shape; epandrium and surstyli rather small (Fig. 116B); surstyli triangular shape T. epichalca (Perkins)

\section{Tomosvaryella oryzaetora Koizumi}

Pipunculus sp., Esaki and Hashimoto, 1932, Ent. Lab. Dept. Agri. Kyushu Imp. Univ., $3: 39$.

Tomosvaryella oryzaetora Koizumi, 1959, Sci. Rept. Fac. Agr., Okayama Univ., 13 : 38. — Hardy, 1972, Proc. Haw. ent. Soc, (1970) 21: 84. — Yano, 1979, Esakia, 13 : 48. — Yano et al., 1984, Trans. Shikoku ent. Soc., 16(4): 64.

Alloneura oryzaetora: Koizumi, 1960, Sci. Rept. Fac. Agr. Okayama Univ., 16 : 34.

\section{M ale.}

Eyes jointed on upperpart of frons for a distance about one half as long as frontal triangle ; frontal triangle entirely cinereous ; occiput cinereous, moderately wide, upperpart much wider than lowerpart ; antennae brownish black, third segment long rostrate.

Thorax and scutellum black, greyish pruinose, almost bare but with some long bristle on notopleuron and dorsocentral line ; humeri black in ground color.

Legs mainly black except apex of femora, narrow base of tibiae and four basal tarsomeres yellow ; front femora with a pair of spines beneath near base four anterior tibiae with posteroapical spur ; mid coxae with a patch of many strong bristles beneath anteriorly, pulvilli slightly smaller than last tarsal segment.

Wings smoky, third costal section about one half as long as the fourth ; r-m situated at middle of discal medial cell, last section of vein Ml slightly undulating ; halteres and calypteres yellowish.

Abdomen subcylindrical, elongate ; all tergites subshining black, conspicuous grey pruinose ; tergite one shortest, with a row of five to six long bristles anterolaterally ; tergites 2-4 subequal in length ; tergite 5 longest, about twice as long as tergite 4 ; tergite 8 (Fig. 118A) rather short about one-third as long as tergite 5, with moderately large membranous area on the right side of the apex.

Genitalia rather small when compared with the abdomen ; epandrium (Fig. 119B) about as wide as long, surstyli moderately long, asymmetrical.

\section{Female.}

Differing from the male as follows : Eyes widely separated, frons entirely cinereous, slightly impressed, slightly wider than face, with a row of short hairs along each side margin from below level of ocelli to middle of frons ; front ommatidial facets slightly enlarged ; ovipositor with subglobular base ; piercer yellowish (Fig. 120B), slightly longer than base, moderately upcurved.

Length : Body $3.5 \mathrm{~mm}$; wing $3.8 \mathrm{~mm}$.

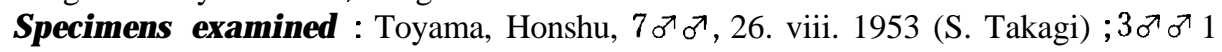
우, Toyama, 20-24. ix. 1958 (S. Takagi) ;2 $\sigma^{7} \sigma^{7} 1$ 우, Toyama, 3. x. 1958 (S. Takagi) ;1 
$0^{7}$, Apoi, Hidaka, Hokkaido, 22. viii, 1957 (T. Kumata) ; 5 우우, Hirakawa, Yamaguchi, Yamaguchi Pref., 5. viii. 1983 (R. Morakote).

Host : Nephotettix cincticeps (Uhler) (Japan, Taiwan), N. nigropictus Stål (Philippines), N. virescens Distant (Philippines), see Yano et al. (1984).

Distribution: Japan (Honshu, Kyushu), Taiwan, Philippines, Thailand, Sabah, Malaya, India.

Remarks : This species seems to be very common in paddy fields in Japan. The biology and morphology of immature stages and mating behavior have been studied by Morakote and Yano (1987, 1988a,1988b).

\section{Tomosvaryella inazumae (Koizumi)}

Alloneura inazumae Koizumi, 1960, Sci. Rept. Fac. Agr. Okayama Univ., 16 : 34.

Tomosvaryella inazumae : Hardy, 1972, Proc. Haw. ent. Soc., 21 (1) : 80. —— Yano et al, 1984, Trans. Shikoku ent. Soc., 16 (4): 67.

This species closely resembles $\mathrm{T}$. oryzaetora in most respects but differs as follows : Generally smaller; wings hyaline ; abdominal tergites metallic black ; front femora without a pair of spines beneath near base ; abdominal sternites 3-5 of male with a band of many spines on each side near posterior margin ; abdominal segment 8 (Fig. 118B) of male about one half as long as tergite 5 ; genitalia clearly different as shown in Fig. 120D ; female ovipositor (Fig. 120C) about 1.5 times as long as base ; moderately downcurved.

Length : Body $3 \mathrm{~mm}$; wing $3 \mathrm{~mm}$.

Specimens examined : 3 지 $^{7 \top 2} 2$ 우우, Mt. Hikosan, Fukuoka Pref., Kyushu, 3. xi. 1985 (R. Morakote) ;1 $\sigma^{7}$, Aichi Pref., Honshu, 13. v. 1963 (T. Okadome) ;1 $\sigma^{7}$, Toyama, Honshu, 29. viii. 1959 (S. Takagi) ;1 우, Toyama, 24. ix. 1958 (S. Takagi).

Host : The zigzag-stripe leafhopper, Recilia dorsalis (Motschulsky) (Hemiptera ; Deltocephalidae), see Koizumi (1960).

Distribution : Japan (Honshu, Kyushu).

\section{Tomosvaryella sylvatica (Meigen)}

Pipunculus sylvaticus Meigen, 1824, Syst. Beschr., 4 : 20.

Tomosvaryella sylvatica: Hardy, 1943, Univ. Kans. Sci. Bull., 29 : 180. —, 1972, Proc. Haw. ent. Soc., (1970) 21: 86. - Yano, 1979, Esakia, $13: 48$; — Yano et al., 1984, Trans. Shikoku, ent. Soc., 16 (4) : 68.

Alloneura sylvatica: Koizumi, 1960, Sci. Rept. Fac. Agr. Okayama Univ., 16 : 39. —Coe, 1966, Handbk. Ident. Brit. Ins., 10 (2C) : 39.

Male.

Head similar to that of T.oryzaetora.

Thorax and scutellum shining black with brownish dusting; almost bare but with some short pubescence on notopleuron and very conspicuous on dorsocentral line ; humeri yellowish white.

Legs mainly deep black except apex of femora, narrow base of tibiae and four 
basal tarsomeres yellow ; mid coxae with a patch of bristles beneath anteriorly ; hind trochanters with a conspicuous group of 5-8 short black spines beneath ; front femora without any spine beneath ; pulvilli slightly smaller than last tarsal segment.

Wings hyaline, third costal section about one-third as long as fourth ; r-m situated at middle of discal medial cell ; last section of vein Ml slightly undulating.

Abdomen metallic black, fairly clothed with long pubescence ; tergite 1 shortest, with a brush of long bristles anterolaterally ; tergites $2-4$ subequal in length, tergite 5 slightly longer than tergite 4 ; tergite 8 (Fig. 118C) rather long, roughly triangular shape, apex compressed to the right, membranous area large occupying on apex clearly seen from above.

Genitalia as shown in Figs. 119D and 121A.

\section{Female.}

Head as that of female of T.oryzaetora; front femora with a pair of conspicuous spines beneath near base, abdominal tergite metallic black, greyish pruinose, tergite 6 longest ; ovipositor (Fig. 120A) with subglobular base, piercer slightly downcurved, about twice as long as base. Otherwise like those of male.

Length : Body 2.3-3.1 mm ; wing 2.3-3.5 mm.

Specimens examined : (Hokkaido) $2 \sigma^{7} \sigma^{7} 2$ 우우, Akankohan, Mt. 0-akan, Kushiro, 3. vii. $1986 ; 7 \sigma^{7} \sigma^{7} 2$ 우우, Shunbetsu, Nemuro, 6. vii. $1986 ; 1 \sigma^{7} 1$ 우, Sounkyo, Kamikawa, 26. vi. 1986 ; 1 우, Kamishibetsu, Kushiro, 5. vii. 1986 ; all were collected by R. Morakote ; Sarobetsu, 12. vii. 1986 (M. Suwa) ; (Kyushu) 107 Hikosan, Fukuoka Pref., 5. vii. 1986 (R. Morakote).

Host : Nephotettix cincticeps (Uhler) (Japan, Taiwan), see Yano et al. (1984); in England Psammotettix striatus (Linnaeus), Arthaldeus pascuellus (Fallen), Diplocolenus bensoni (China), Errastunus ocellaris (Fallen), see Waloff (1975, 1980).

Distribution : Widely spread over the world.

\section{Tomosvaryella coquilleti(Kertész)}

Pipuculus coquiletti Kertész, 1907, Annal. Mus. Nat. Hung., 5 : 582.

Tomosvaryella coquiletti: Hardy, 1943, Univ. Kans. Sci. Bull., $29: 159 . \quad$ Y Yano et al., 1984, Trans. Shikoku ent. Soc., 16(4): 68.

Alloneura coquilletti: Koizumi, 1960, Sci. Rept. Fac. Agr. Okayama Univ., 16 : 38.

This species is very similar to T.sylvatica (Meigen) but differs as follows : Body coloration not conspicuous metallic black as sylvatica; hind trochanters with only one or two spines beneath ; abdominal tergite 8 of male (Fig. 118D) roughly perpendicular dorsally, with conspicuous membranous area dorsomedially ; epandrium (Fig. 119C) with median longitudinal groove, surstyli narrow, clearly different from that of sylvatica; female ovipositor is very much difficult to distinguish from that of sylvatica.

Length : Body 2.4-2.9 mm; wing 2.5-3 mm.

Specimens examined : (Kyushu) Hikosan, Fukuoka Pref., 16, 4. ix. 1985 (R.

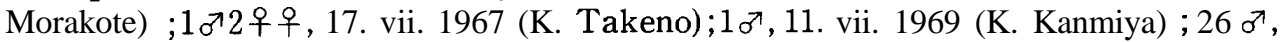
Mt. Kuju, Oita Pref., 5. vii. 1985 (R. Morakote) ; 1 우, Yakushima, Kagoshima Pref., 4. vii. 1972 (T. Okadome) ; (Honshu) $1 \sigma^{7}$, Katsuraya, Yamagoshi, Niigata, 27. vii. 1971 (K. 
Yamagishi) ; $1 \sigma^{7}$, Kurohime Yama, Nagano, 8. vi. 1959 (K. Kamijo). (Hokkaido) $1 \sigma^{7} 1$ ㅇ. Akankohan, Mt. 0-akan, Kushiro, 4. vii. 1986 (R. Morakote) ;1 $\sigma^{71}$ 우, Esasi, 13. ix. 1958 (S. Takagi) ; 1 우, Aizankei, 15. vii. 1960 (K. Kamijo) ;1 ð , Zenibako, 3. vii. 1960 (S. Takagi).

H ost : Unknown.

Distribution : Japan (Hokkaido, Honshu, Kyushu, Okinawa), America and Europe.

\section{Tomosvaryella epichalca (Perkins)}

Pipunculus epichalchus Perkins, 1905, Bull. exp. Stat. Hawaii. Sugar Pl. Ass., 1 (4) : 150. Tomosvaryella epichalca : Hardy, 1968, Ent. Meddelelser, 36 (5) : 482 ; - , 1972, Oriental Insect Suppl. $2: 71$. — Yano et al., 1984, Trans. Shikoku ent. Soc., 16 (4) : 69.

Male (Fig. 116A).

Moderately large species. Ocellar triangle shining black ; eyes joined on upperpart of frons for a short distance about half as long as frontal triangle ; frontal triangle cinereous ; antennae all brownish black, second segment with some short bristles above and beneath, third segment long acuminate.

Thorax and scutellum almost bare, subshining black; humeri yellow.

Legs almost entirely black except apex of femora and narrow base of tibiae yellowish ; femora and trochanters without any spine beneath near base ; pulvilli as long as last tarsal segment.

Wings hyaline, third costal section short, about one-fourth of next costal section ; $\mathrm{r}-\mathrm{m}$ situated slightly after middle of discal medial cell ; last section of vein Ml slightly undulating.

Abdomen cylindrical, bare, metallic black ; almost bare; tergites 2-4 subequal in length ; tergite 5 longest; tergite 8 rather short, about one-fourth as long as tergite 5 , with small exclavate membranous area which is clearly seen only from ventral and behind ; epandrium and surstyli (Fig. 121B) rather small.

Female.

Eyes widely separated, slightly convex on upperpart, shining black on anterior half but remainder cinereous, with a row of short hairs along each lateral margin ; pulvilli slightly larger than last tarsal segment ; ovipositor much like that of $\mathbf{T}$. oryzaetora. Otherwise similar to the male.

Length : Body $4.2 \mathrm{~mm}$; wing $4.7 \mathrm{~mm}$.

Specimens examined : 16, Yakushima, Kagoshima Pref., Kyushu, 17. v. 1986 (Y. Sawada);1 $1 \sigma^{7}$, Aburayama, Fukuoka, Fukuoka Pref., Kyushu, 3. vi. 1967 ; 1 우, same data ; 16, Nakajin, Okinawa Island, 12. iv. 1964 (Bishop coll.);1우, Tempaku, Nagoya, Aichi Pref., 30. ix. 1985 (K. Yamagishi).

Host : Nephotettix cincticeps (Uhler) (Japan), see Yano et al. (1984).

Distribution : Japan (Honshu, Kyushu, Okinawa), Taiwan, Philippines, Cambodia and Australia. 


\section{Tomosvaryella subvirescens (Loew)}

Pipunculus subvirescens Loew, 1872, Berlin. ent. Zschr., $16: 87$.

Tomosvaryella subvirescens : Hardy, 1943, Univ. Kans. Sci. Bull., 29 : 178. - - 1972, Proc. Haw. ent. Soc., 21: 86. — Yano, 1979, Esakia, 13: 48. — Yano et al., 1984, Trans. Shikoku ent. Soc., 16 (4) : 69.

\section{M ale.}

Head as that of T. oryzaetora.

Thorax and wing as those of T. epichalca.

Legs mainly brownish black except apex of femora, narrow base of tibiae and four basal tarsomeres yellow ; front femora with a single spine beneath near base ; front trochanters with a few spines beneath; hind trochanters conspicuously flattened beneath (Fig. 118F) ; pulvilli as long as last tarsal segment.

Abdomen brownish black, fairly clothed with short pubescence, rather stout ; tergite 8 (Fig. 118E) rounded posteriorly as seen from above, with large membranous area on the right ; epandrium (Fig. 119A) very much swollen but surstyli rather small, asymmetrical.

Length : Body $2.8 \mathrm{~mm}$; wing $3 \mathrm{~mm}$.

Specimen examined : 16, Miyako Island, Okinawa, 27. x. 1952 (G. E. Bohart) (Bishop Coll.).

Host : Nephotettix cincticeps (Uhler) (Japan, Taiwan); N. nigropictus Stål (Philippines) ; N. virescens Distant (Philippines), Circulifer tenellus (Baker) (USA- not from paddy fields), see Yano et al. (1984).

Distribution : Japan (Okinawa), Philippines, Thailand, Laos, Malaya, India, Micronisia, America and Africa.

\section{Tomosvaryella caliga ta Hardy}

Tomosvaryella caligata Hardy, 1968, Ent. Meddelelser, 36 : 481.

$M$ ale.

This species closely resembling T. epichalca in many respects but differing as follows : Body coloration not cospicuously metallic black as epichalca, abdominal tergite 8 somewhat rounded posteriorly when viewed from above ; genitalia with boot-shaped surstyli (Fig. 117A and C).

Length : Body $3.5 \mathrm{~mm}$; wing $3.5 \mathrm{~mm}$.

Female : Unknown.

Specimen examined : $1 \sigma^{\nwarrow}$, Okinawa, -. vi. 1958 (N. L. M. Krauss) (Bishop Coll.).

Host : Unknown.

Distribution : Japan (Okinawa), Philippines.

Remarks : This is the first record of this species from Japan.

\section{Tomosvaryella itoi (Koizumi)}

Alloneura itoi Koizumi, 1960, Sci. Rept. Fac. Agr. Okayama Univ., 16 : 36. 
Tomosvaryella itoi: Hardy, 1971, Proc. Haw. ent. Soc., 21 (1) : $80 ;-, 1972$, Oriental Insect Suppl., 2:73.

Host : Unknown. Koizumi (1960) suggested that it may have some host relations to Psammotettix striatus (Linnaeus).

Distribution : Japan (Honshu) and Philippines.

Remarks : This species seems to be rare in Japan because of no record after Koizumi (1960). The original description by Koizumi (1960) is good. His important remarks on this species are as follows : This species is related to Alloneura kuthi (Aczél) not only in having the outstanding posteroventral cilia on the hind femora and the black colored tarsi, but also in having the genitalia with a large depressed area at the tip. However it is distinguished from $A$. kuthi by the ninth tergite of the male genitalia without a longitudinal groove on the mid line from ventral view, the claspers broad triangular in outline, also the female ovipositor extending to the base of the third abdominal segment and the piercer only one and one-fourth times as long as the base, instead of the ovipositor extending to the base of the second abdominal segment and the piercer twice the length of the base in A. kuthi.

\section{REFERENCES}

Aczél, M. 1939a Das System der Familie Dorylaidae. Dorylaiden-Studien 1. Zool.Anz., 125: 15-23

— 1939b Die Untergattung Dorylomorpha m. von Tomosvaryella m. Dorylaiden-Studien 2. Zool. Anz., $125: 46-69$

- 1939c Bekerias pannonicus, eine neue Gattung und Art der Dorylaiden (Diptera). DorylaidenStudien 4. Zool.Anz., 126: 191-195

1940 Vorarbeiten zu einer Monographie der Dorylaiden (Dipt.). Dorylaiden-Studien 5. Zool. Anz., 132 : 149-169

1944 Die Gattung Tomosvaryella Acz. (Dipt.) (Dorylaiden-Studien 8). Ann. hist. nat.Mus.natr. hung., $37: 75-130$

- 1948 Grundlagen einer Monographie der Dorilaiden (Diptera). Dorilaiden-Studien 6. Acta Zool. Lilloana, Tucuman, $6: 5-168$

Albrecht, A. 1979 Description of seven new Dorylomorpha Aczél species from Europe (Diptera : Pipunculidae). Ent. Scand., 10 (3) : 211-218

Andersson, H. 1972 En Snabb och Billing Metod att Montera Genital preparat I Glycerin. Enttomologen, 1 (2) : 1-2

Becker, T. 1897 Dipterologische Studien 5. (Pipunculidae). Berl.ent.Z., $42: 25-100$

1900 Dipterologische Studien 5. Pipunculidae. Erste Fortsetzung. Berl. ent. Z., 45: 215-252

Brunetti, E. 1912 New Oriental Diptera, 1. Rec. Indian. Mus., 7: 445-513

1923 Pipunculidae, Syrphidae, Conopidae, Oestridae. In Fauna of British India. Diptera $3: 1$ 424

Chandra, G. 1978 Natural enemies of rice leafhoppers and planthoppers in the Philippines. Int. Rice Res. Newsletter, 3 (5) :20-21

Chu, Yau-i and Y. Hirashima 1981 Survey of Taiwanese literature on the natural enemies of rice leafhoppers and planthoppers. Esakia, (16) : 33-37

Coe, R. L. 1966a Some British species of Chalarus and Verrallia (Diptera : Pipunculidae). Proc.r. ent. Soc. Lond., (B) 35: 149-160

— 1966b Diptera Pipunculidae. Handbk. Ident. Brit. Insects. (Diptera, Pipunculidae). R. ent. Soc. Lond., 10 (2C) : 1-83

Collin, J. E. 1931a Die Ausbeute der Deutschen Chaco-Expedition 1925/26. Diptera. 29, Pipun- 
culidae. Konowia, Wien, 10: 171-176

— 1931 The British species of the genus Verrallia (Diptera). Ent. mon. Mag., 67 : 234-236

— 1937 The British species of the rufipes group of Pipunculus (Diptera). Ent. mon. Mag., $73: 209$ 218

1941 Some Pipunculidae and Empididae from Ussuri Region of the Far Eastern border of the USSR. (Diptera). Proc.r. ent. Soc. Lond., (B) 10: 218-224, 225-248

1945 Notes on some recent work on the Pipunculidae (Diptera). Ent. mon. Mag., 81 : 1-6

- 1956 Scandinavian Pipunculidae. Opusc. Ent., 21: 149-169

Coquillett, D. W. 1910 The type-species of the North American genera of Diptera. Proc.U. S. nat. Mus., 37 : 499-647

Cresson, E. T. 1911 Studies in North American Dipterology : Pipunculidae. Trans. Amer. ent. Soc., $36: 291-329$

Duda, 0. 1940 Neue oder ungeniigend bekannte Zweifltigler der palaarktischen Region aus meiner Sammlung. Folia zool. Hydrobiol., 10 : 214-226

Egger, J. 1860 Dipterologische Beiträge. Verhandlungen der zool.-bot.Gesellschaft in Wien., 10 : 347

Enderlein, G. 1936 Zweiftigler, Diptera.pp. 128-129. In Brohmer, P., Ehrmann, G. and Ulmer, G. (eds.), Die Tier-welt Mitteleuropas 6, Insekten $3: 1-259$

Esaki, T. and S. Hashimoto 1932 Report on the leafhoppers injurius to the rice plant and their natural enemies. Ent. Lab. Dept. Agr., Kyushu Imp. Univ. Pub., 3: 42 pp (In Japanese)

- 1934 Ditto. Ibid., 5 : 30-32 (In Japanese)

1935 Ditto. Ibid., 6 : 24-25 (In Japanese)

1936 Ditto. Ibid., $7: 21-22$ (In Japanese)

Esaki, T., S. Hashimoto and T. Sameshima 1937 Ditto. Ibid., 8 : 24-25 (In Japanese)

Esaki, T. and T. Sameshima, 1938 Ditto. Ibid., 9: 22-23 (In Japanese)

— 1939 Ditto. Ibid., 10:45-47 (In Japanese)

- 1940 Ditto. Ibid., 11: 40-41 (In Japanese)

Esaki, T. and M. Mochizuki 1941 Ditto. Ibid., 12: 31-33 (In Japanese)

Fallén, C. F. 1810 Specimen entomologicum novam Diptera disponendi methodum exhibiens. Dissertatio, Lund,: I-26

— 1816 Syrphici Sveciae. Lundae (=Lund) : Part 1: 1-14 ; Part 2:15-22

Freytag, P. H., 1985 The insect parasites of leafhoppers, and related group. pp. 423-465. In Nault, L. R. and J. G.Rodriquez, The Leafhoppers and Planthoppers. New York. 500 pp

Haliday, A. H. 1833 Catalogue of Diqtera occurring about Hollywood in Downshire. Ent. Mag., 1 : 147-180

Hardy, D. E. 1943 A revision of Nearctic Dorilaidae (Pipunculidae). Univ. Kans. Sci. Bull., 29 (1) : $1-231$

— 1948 New and little known Diptera from the California Academy of Sciences Collection (Rhagionidae and Dorilaidae). Wasmann Collector, 7 (4) : 129-137

- 1950 Dorilaidae (Pipunculidae) (Diptera). Explor.Parc nat. Albert, Miss. de Witte (19331935), $62: 53 \mathrm{pp}$

— 1968 Bibionidae and Pipunculidae of the Philippines and Bismarck Islands (Diptera). Ent. Meddelelser., 36 (5) : 417-507

— 1972a Pipunculidae (Diptera) of the 1934 Swedish Expedition to Burma. Zoologica Scripta, 1 (3/4): 121-138

1972b Pipunculidae (Diptera) parasitic on rice leafhoppers in the Oriental region. Proc. Haw. ent. Soc., 21 (1) : 79-91

1972c Studies on Pipunculidae (Diptera) of the Oriental Region, Part 1.Oriental Insects, Suppl. 2, 76 PP

— 1987 Family Pipunculidae, pp. 745-748. In McAlpine J. F. et al. (eds.), Manual of Nearctic Diptera 2. Research Branch, Agriculture Canada, Canada 
International Commission on Zoological Nomenclature, 1961, Opinion 597. Prothechus Rondani, 1856 and Alloneura Rondani, 1856 (Insecta, Diptera), suppressed under the Plenary Powers. Bull. Zool. Nomencl., 18 : 230-235

1963 Opinion 678. The suppression under the Plenary Powers of the pamphlet published by Meigen, 1800. Bull. Zool. Nomencl., 20: 339-342

Jervis, M. A. 1980a Studies on oviposition behaviour and larval development in species of Chalarus (Diptera, Pipunculidae), parasites of typhlocybine leafhoppers (Homoptera, Cicadellidae). J. nat. Hist., 14 : 759-768

— 1980b Life history studies on Aphelopus species (Hymenoptera, Dryinidae) and Chalarus species (Diptera, Pipunculidae), primary parasites of typhlocybine leafhoppers (Homoptera, Cicadellidae). J. nat. Hist., 14 : 769-780

- 1980c Ecological studies on the parasite complex associated with typhlocybine leafhoppers (Homoptera, Cicadellidae). Ecol. Ent., 5 (2) : 123-136

Kertész, C. 1901 Catalogus Pipunculidarum huc usque ad finemanni 1900 decscriptarum. Termés. Fïzetek, 24: 157-168

1907 Vier neue Pipunculus.Arten. Annlshist.-nat.Mus. natn. hung., 5 : 579-583

- 1910 Catalogus Dipterorum hucusque descriptorum 7. Budapest, $470 \mathrm{pp}$

1912 H. Sauter's Formosa-Ausbeute. Dorylaidae (Dipt.). Annls hist.-nat.Mus. natn. hung., $10: 285-299$

Koizumi, K. 1959 On four Dorilaid parasites of the green rice leafhopper, Nephotettix cincticeps (Uhler) (Diptera). Sci. Rep. Fac. Agric. O kayama Univ., 13: 37-45

1960 A new Dorilaid parasites of the zig-zag-striped leafhopper, Inazumadorsalis (Motschuls ky) and notes on other paddy field inhabiting Dorilaidae (Diptera). Sci. Rep.Fac. Agric. Okayama Univ., 16: $33-42$

Kowarz, F. 1887 Beiträze zu einem Verzeichnisse der Dipteren Böhmens VI. Conopidae, Pipunculidae. Wein. ent. Ztg., 6: 146-154

Kozanêk, M. 1981 Genus Pipunculus Latreille (Diptera, Pipunculidae) in Czechoslovakia. Annotationes zool. bot. Bratislava, $142: 1-16$

— 1987 The Pipunculid genus Cephalops Fallên (Diptera) in Czechoslovakia. Annot.zool.bot., Bratislova, $180: 1-19$

Latreille, P. A. 1802 Histoire Naturalle générale et particuliére des Crustacés et des Insectes. Paris, 3: I-467

— 1804 Histoire Naturalle gênérale et particuliêre des Crustacés et des Insectes. Paris, 14 : I-432

Lauterer, P. 1981 Contribution to the knowledge of the family Pipunculidae of Czechoslovakia (Diptera). Acta.Mus.morav. (Sci. nat.), 66 : 123-150

Lin, Kwei-shui 1974 Notes on some natural enemies of Nephotettix cincticeps (Uhler) and Nilapar vatalugens (Stål) in Taiwan. Jour. Taiwan Agr. Res., 23: 91-115 (In Chinese with English summary)

Linnane, J. P. and E. A. Osgood 1977 Verralliavirginica (Diptera : Pipunculidae) reared from the Saratoga spittle bug in Maine. Proc. Ent. Soc. Wash., 79 (4) : 622-623

MacAlpine, J. F. 1981 Morphology and Terminology-Adults. pp. 9-63. In MacAlpine et al. (eds.). Manual of Nearctic Diptera 1. 674 pp. Research Branch, Agriculture Canada, Canada

Macquart, J. 1834 Insects Diptères du Nord de la France. Recueil des travaux de la société d' amateurs des sciences de 1' agriculture et des arts de Lille (1833), $356 \mathrm{pp}$

1835 Histoire naturelle des Insectes. Dipteres, 2 : 1. In Robet, N. E. (ed.), Collection des suites a Buffon, Paris

Matsumura, S. 1918 Thousand Insects of Japan. Additementa ii. Tokyo (185-473)

— 1931 Six Thousand Illustrated Insects of Japan-Empire. Toukou Shoin, Tokyo

May. Y. Y. 1979 The biology of Cephalops curtifrons (Diptera : Pipunculidae), an endoparasite of Stenocranus minutus (Hemiptera : Delphacidae). Zool. Jour. Linnean Soc., 66 (1) :15-29 
Meigen, J. W. 1800 Nouvelle classification des mouches à deux ailes (Diptera L.), d' après un plan tout nouveau. Paris, : 1-40. (This publication has been suppressed by the International Commission on Zoological Nomenclature. Bull. Zool. Nom. I. C. Z. N., 1963 : Opinion 678)

1803 Versuch einer neuen Gattungseintheilung der europaischen zweiflügeligen Insekten. Mag. Insektenk., $2: 259-281$

$18-24$

— 1838 Systematische Beschreibung der bekannten europäischen zweifltigeligen Insekten (Supplementary volume). Hamm, $7:$ XII+ 1-434

Meyer, M. and L. Bruyn 1985 On the occurrence of Pipunculidae in Belgium. Documents. Trav. Inst. Nat. Belg., 24: 1-52

Mik, J. 1889 Verrallia nov. gen. Pipunculidarum. Wien. ent. Zeitg., $18: 133-137$

Morakote R. 1988 Four new species of Nephrocerus Zetterstedt (Diptera : Pipunculidae) from Japan. Esakia, (26) :79-90

Morakote R. and K. Yano 1987 Morphology of immature stages of some Japanese Pipunculidae (Diptera) parasitizing Nephotettix cincticeps (Uhler) (Hemiptera : Deltocephalidae). Kontyu, Tokyo, 55 (2) : 176-186

— 1988a Biology of some Japanese Pipunculidae (Diptera) parasitizing Nephotettix cincticeps (Uhler) (Hemiptera, Deltocephalidae). Bull. Fac. Agric. Yamaguchi Univ., $35: 9-22$

— 1988b Adult behavior of some Japanese Pipunculidae (Diptera) parasitizing Nephotettix cincticeps (Uhler) (Hemiptera, Deltocephalidae). Kontyâ, Tokyo, 56 (3) : 653-658

Perkins, R. C. L. 1905 Leafhoppers and their natural enemies (Pt. IV. Pipunculidae). Experiment Sta. Hawaii. Sugar Planters Assoc., Bull., 1 (4) : 123-157

Rondani, C. 1856 Dipterologiae Italicae. Prodromus. Parmae, 139-140

Roser, C. L. F. von. 1840 Erster Nachtrag zu dem in Jahre 1834 bekannt gemachten Verzeichnisse in Wiirttemberg vorkommender zweifliigliger Insektan. Corresp.wiirtt.landw.Ver. Stuttg., (N. S.), 17 (1) : 49-64. : $55 \mathrm{pp}$

Rothschild, G. H. L. 1964 The biology of Pipunculus semifumosus (Kowarz) (Diptera :Pipunculidae), a parasite of Delphacidae (Homoptera), with observation on the effects of parasitism on the host. Parasitology, $54: 763-769$

Sack, P. 1935 Dorylaidae (Pipunculidae). In Lindner, Flieg. palaarkt. Reg., Bd. 4, 32, 58 pp

Schiner, J. R. 1862 Fauna Austriaca. Die Fliegen. I, 245

Schummel, T. E. 1837 Ueber die Guttung Sryphus und vier neue Arten derselben. Uebers. schles. Ges. vaterl. Kult., $1836: 84-85$

Thompson, F. C. 1977 Verralliavirginica Banks, a valid species (Diptera : Pipunculidae). Proc. ent. Soc., Wash. 79 (4) : 624-625

Verrall, G. H. 1901 Platypezidae, Pipunculidae and Syrphidae of Great Britain. British Flies 8. London, : 1-691

Walker, F. A. 1834 Observations of the British species of Pipunculidae. Ent. Mag. London, 2 :262270

Waloff, $N .1975$ The parasitoid of the nymphal and adult stages of leafhoppers (Auchenorrhyncha : Homoptera) of acidic grassland. Tran.r. ent. Soc. London, 126 (4) : 637-686

- 1980 Studies on grassland leafhoppers (Auchenorrhyncha, Homoptera) and their natural enemies. Adv. ecol. Res., 11: 81-215

Westwood, J. 0. 1840 Order 8. Diptera Aristotle. pp. 125-154. In Synopsis of the genera of British Insects, pp. 188, In An Introduction to modern classification of Insects, London

Williams, F. X. 1919 Some observations on Pipunculus flies which parasitize the cane leafhopper, at Pahala, Hawaii, Feb 11-April 25, 1918 Proc. Haw. ent. Soc., $4:$ 68-71

Williams, J. R. 1957 The sugarcane Delphacidae and their natural enemies in Mauritius. Trans. $r$. ent. Soc. Lond., 109: 65-110

Whittaker, J. B. 1968 Polymorphism of Philaenus spumarius (L.) (Homoptera, Cercopidae) in 
England. J. anim. Ecol., 37: 99-111

1969 The biology of Pipunculidae (Diptera) parasitising some British Cercopidae (Homoptera). Proc.r. ent. Soc. Lond., (A) 44: 17-24

Yano, K. 1979 Faunal and biological studies on the insects of paddy fields in Asia. Part II. Illustrated key to the Thai species of Pipunculidae (Diptera). Esakia, (13) : 45-54

Yano, K., M. Ishitani, I. Asai and M. Satoh 1984 Faunal and biological studies on the insects of paddy fields in Asia. XIII. Pipunculidae from Japan (Diptera). Trans. Shikoku ent. Soc., 16 (4) : 53-74

Zetterstedt, J. W. 1838 Insecta Lapponica. Leipzig. Sectio tertia, Diptera, pp. 578-579

1844 Diptera Scandinaviae. Disposita et descripta. Lund, 3 : 949-969 

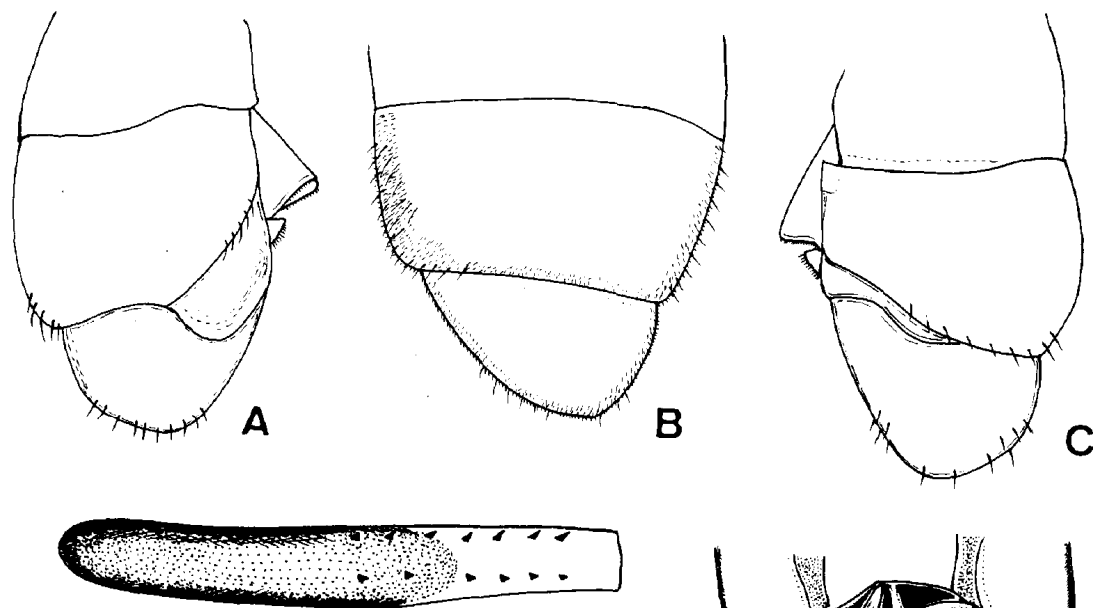

$E$
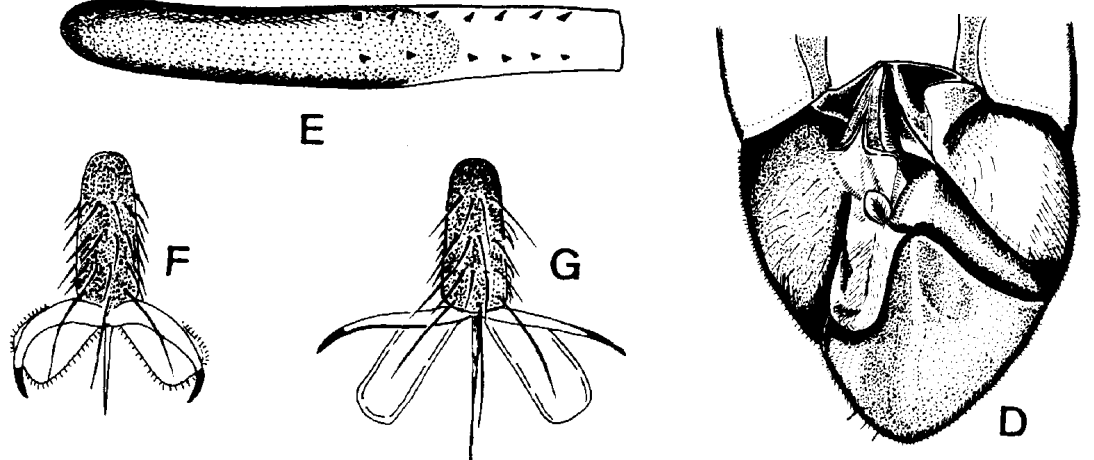

Fig. 104. Dorylomorpha confusa (Verrall) (A-F, male) : A-D. Abdominal terminalia (A. right side, B. dorsal, C. left side, D. ventral) ; E. mid femur, beneath ; F and G. last tarsal segment (F. male, G. female). 


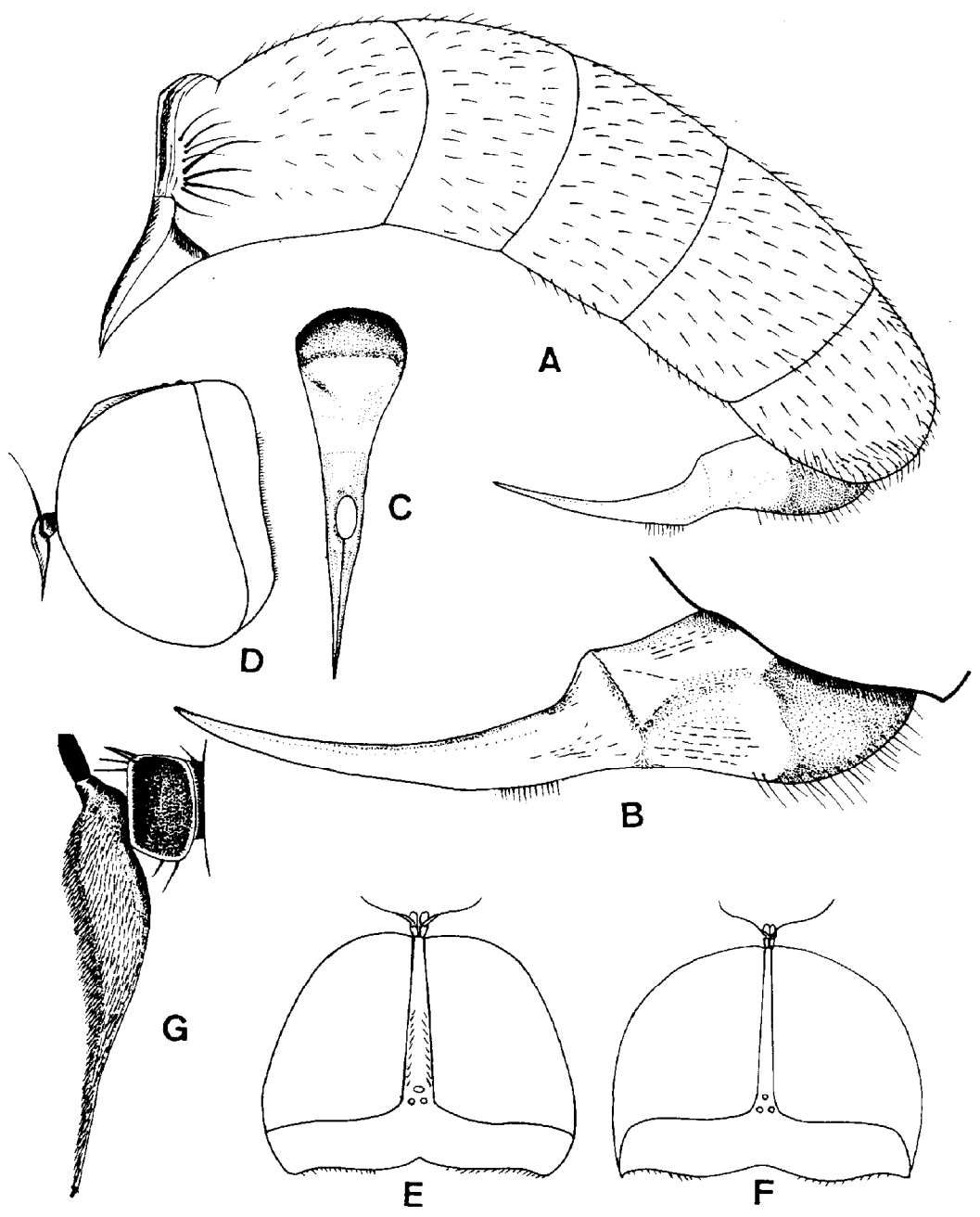

Fig. 105. Dorylomorpha confusa (Verrall) : A. Female abdomen, lateral ; B and C. ovipositor (B. lateral, C. ventral) ; D and E. female head (D. lateral, E. dorsal) ; F. male head, dorsal ; G. antenna. 


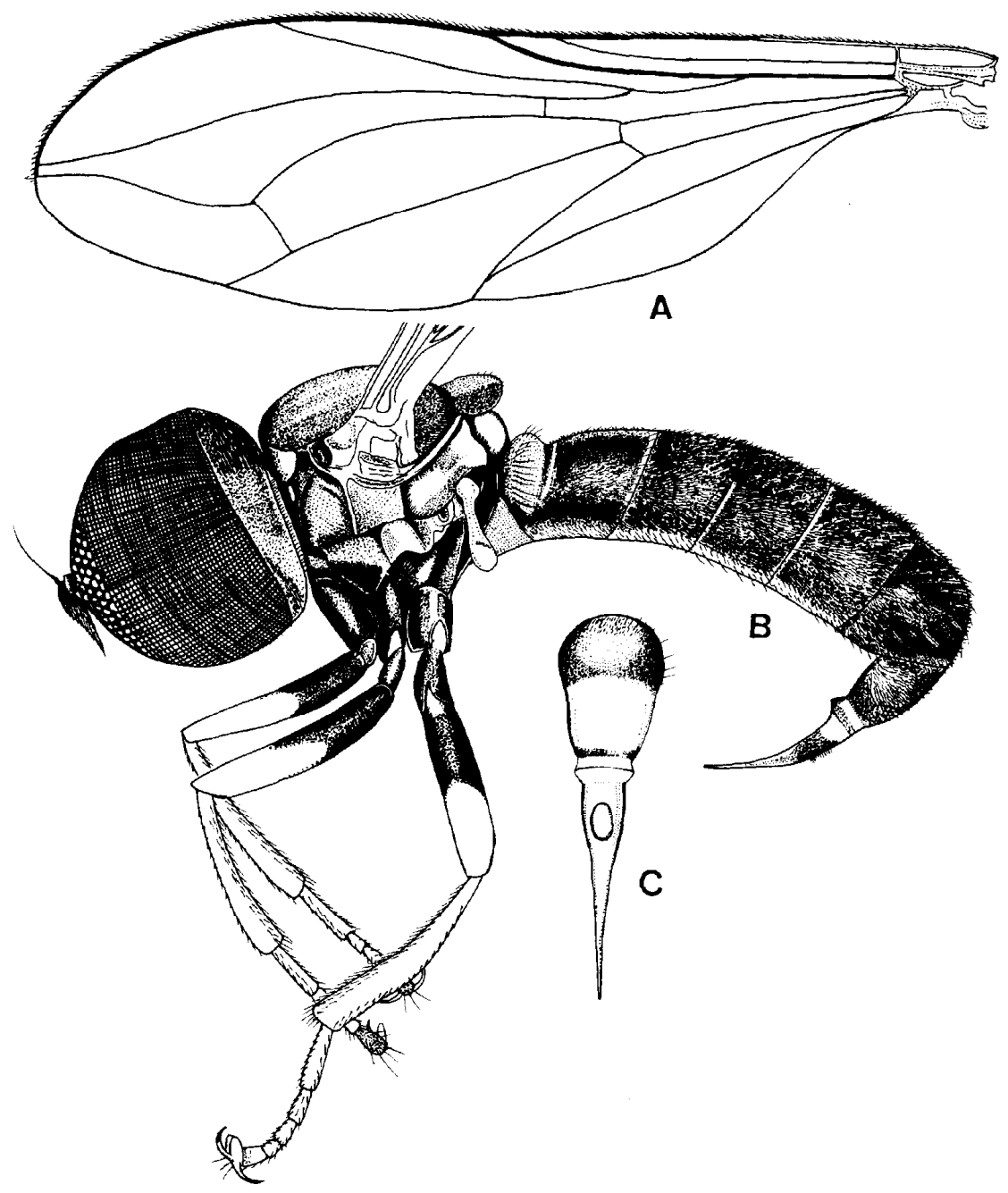

Fig. 106. Dorlylomorpha confusa (Verrall) (female) : A. Wing ; B. body, lateral ; C. ovipositor, ventral. 


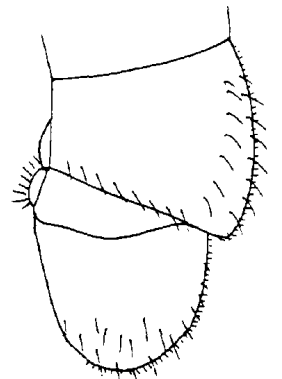

A
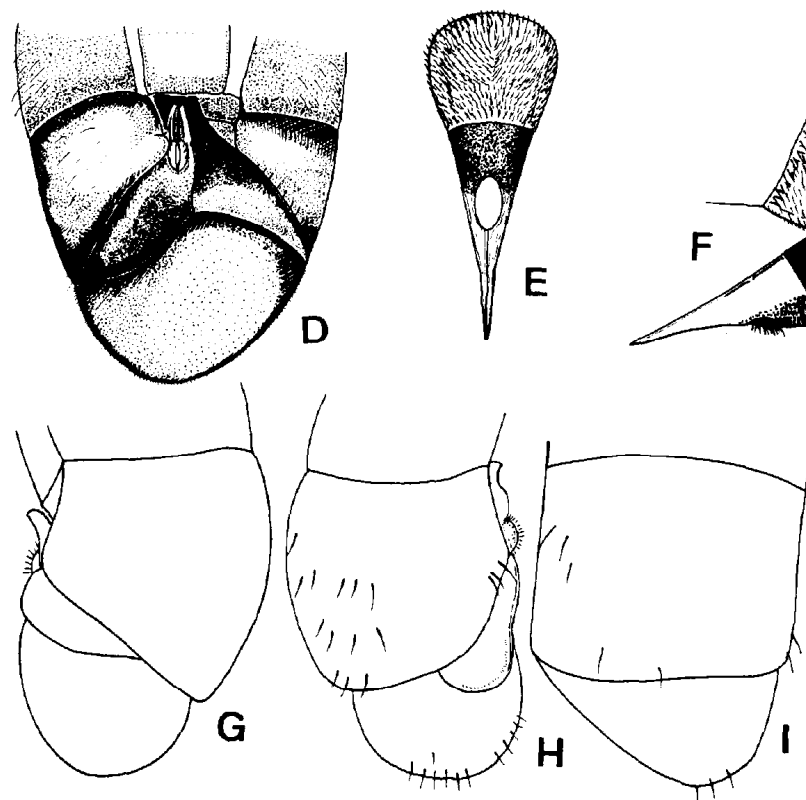

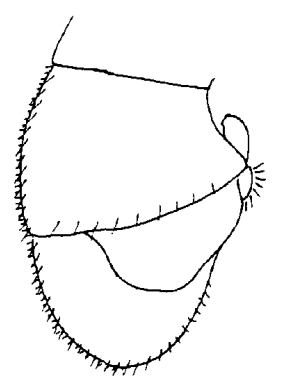

C

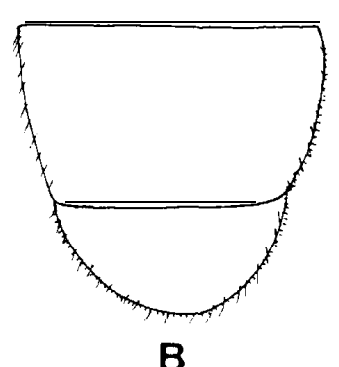

B

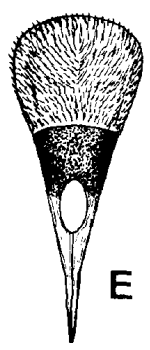

$E$
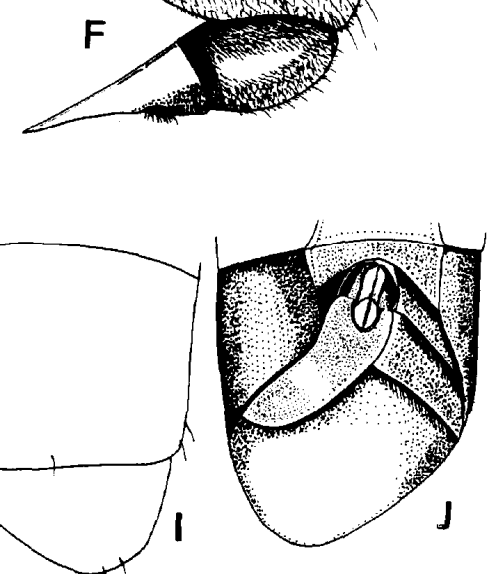

Fig. 107. A-F. Dorylomorphaimparata (Collin) : A-D. Male abdominal terminalia ; E and F. female ovipositor. G-J. Male abdominal terminalia of E. kurodakensis Morakote et Yano, sp. n. 

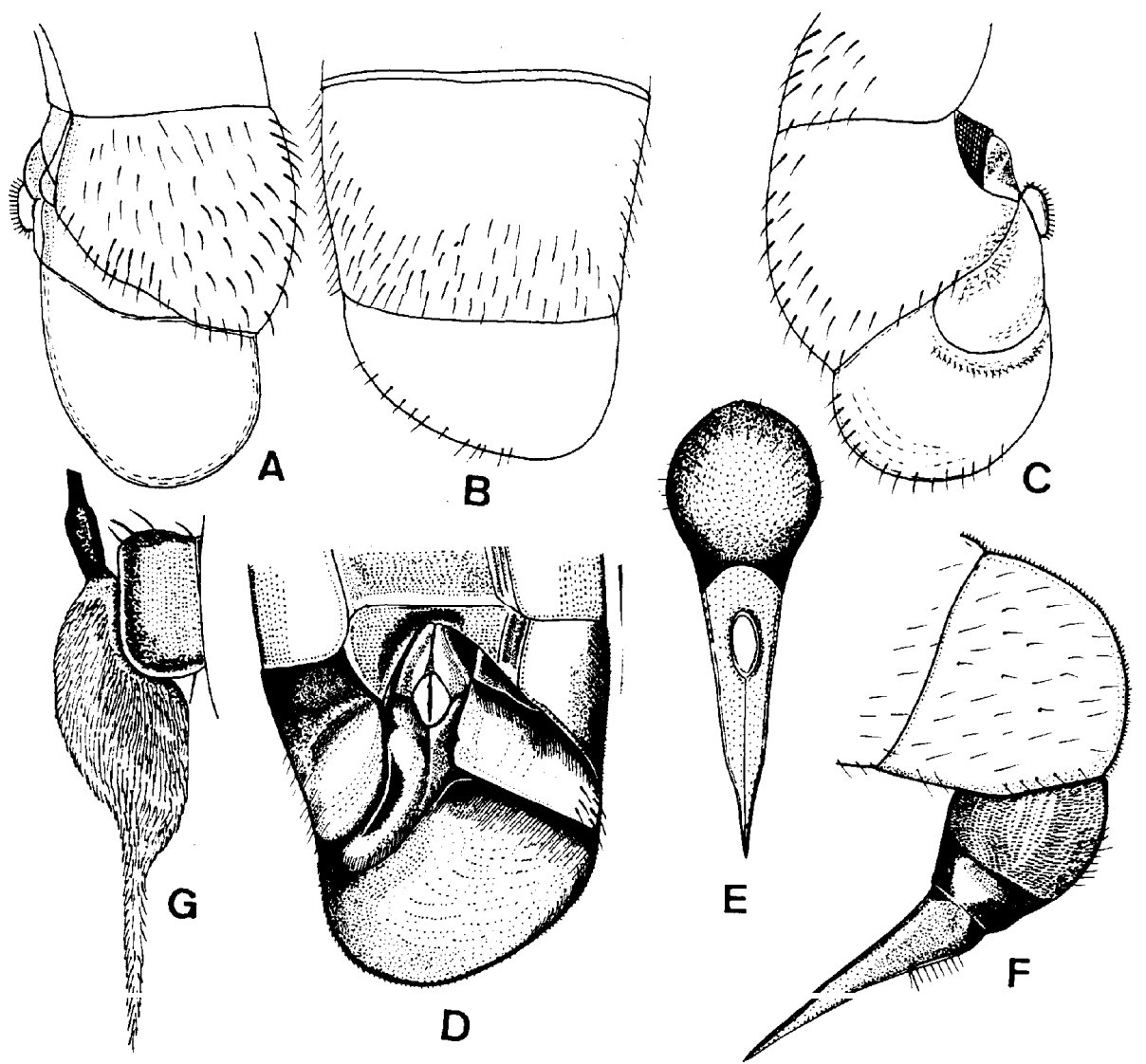

Fig. 108. Dorylomorpha extricata (Collin) A-D. Male abdominal terminalia ; E and F. female ovipositor; G. antenna. 


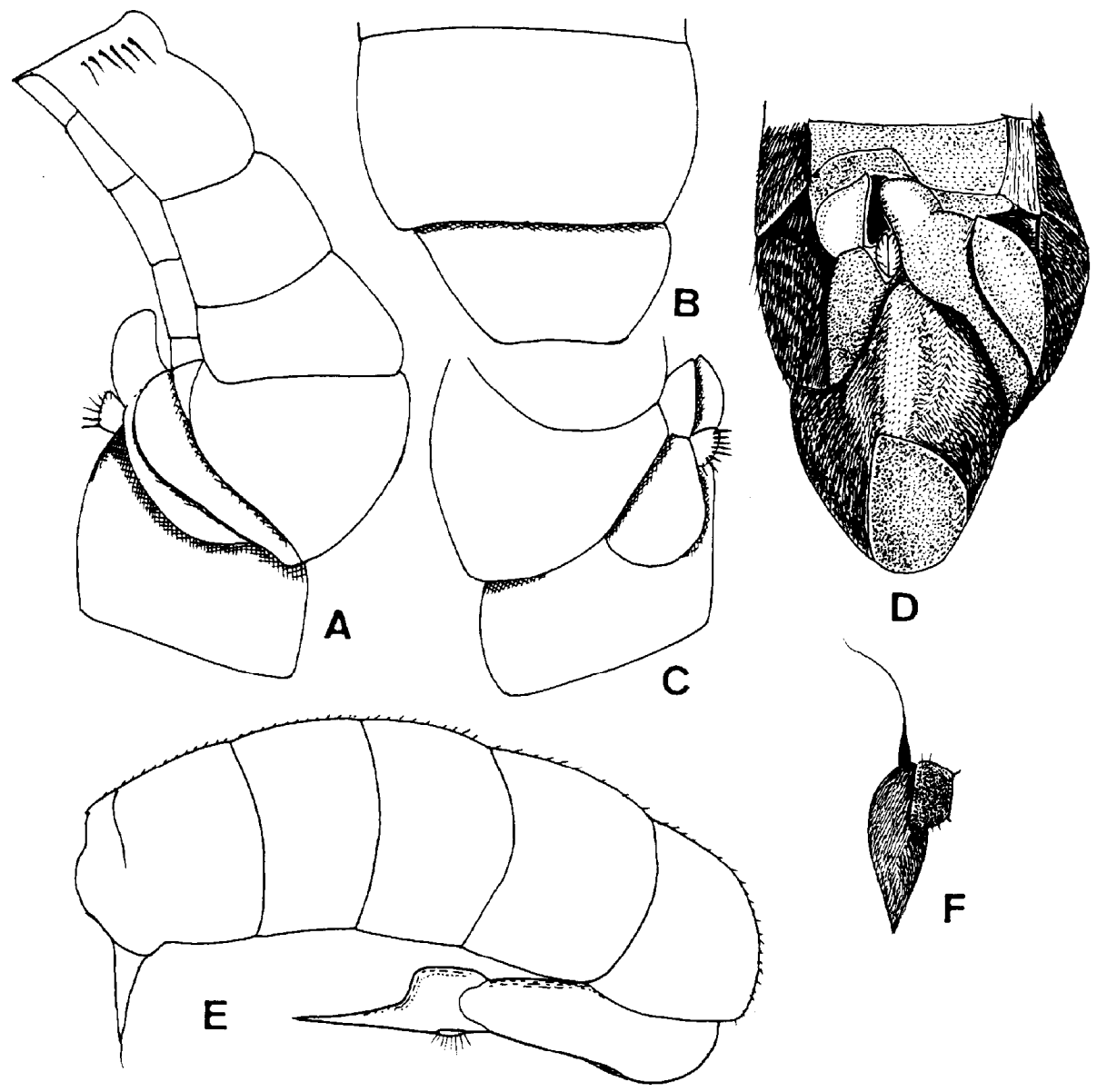

Fig. 109. Dorylomorpha haemomhoidalis (Zetterstedt) : A-D. Male abdominal terminalia ; E. female abdomen ; F antenna. 

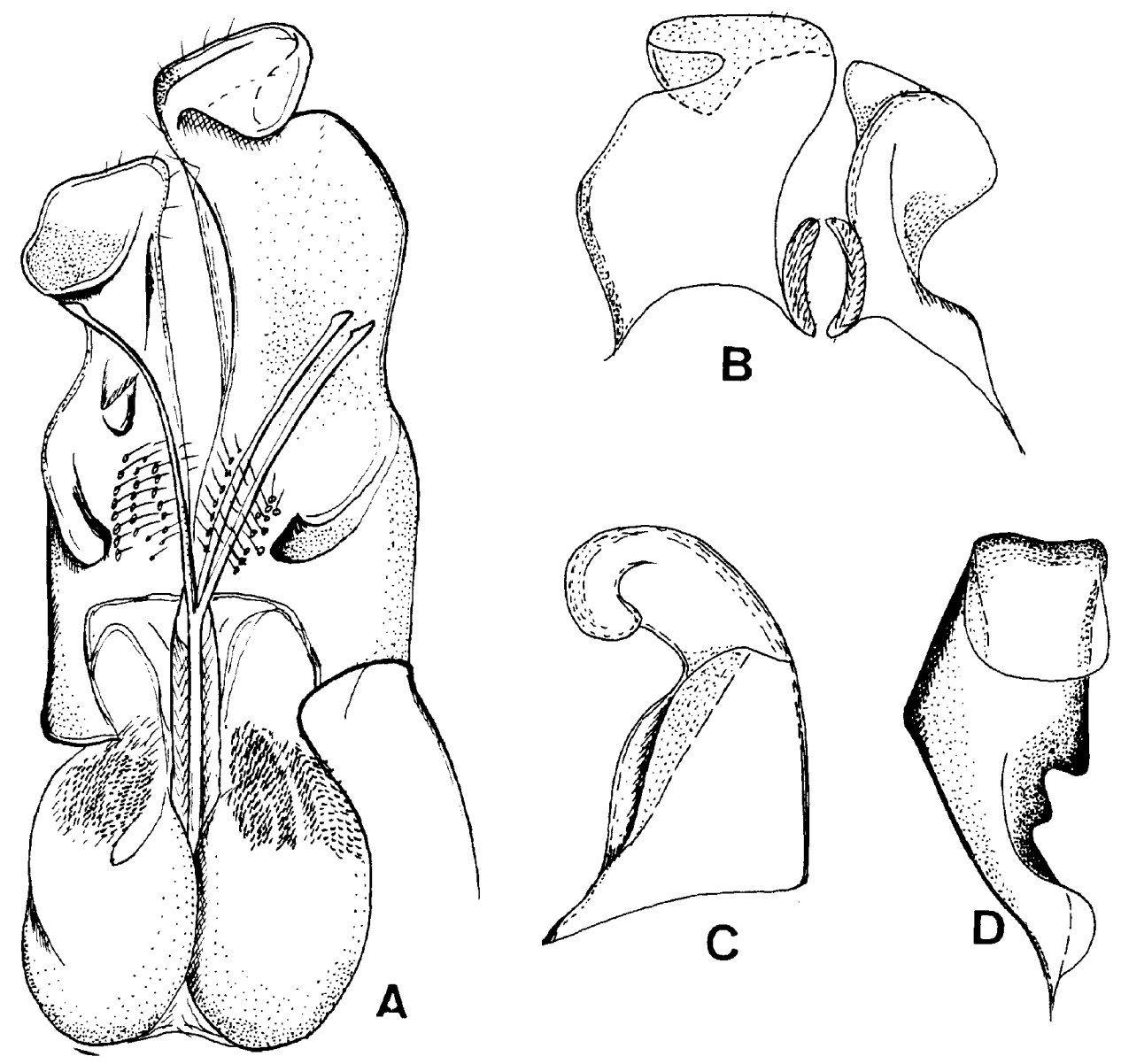

Fig. 110. Dorylomorphahaemorrhoidalis (Zetterstedt) (male) : A. genitalia, dorsal ; B. surstyli, dorsal ; C. left surstylus; D. right surstylus, lateral. 


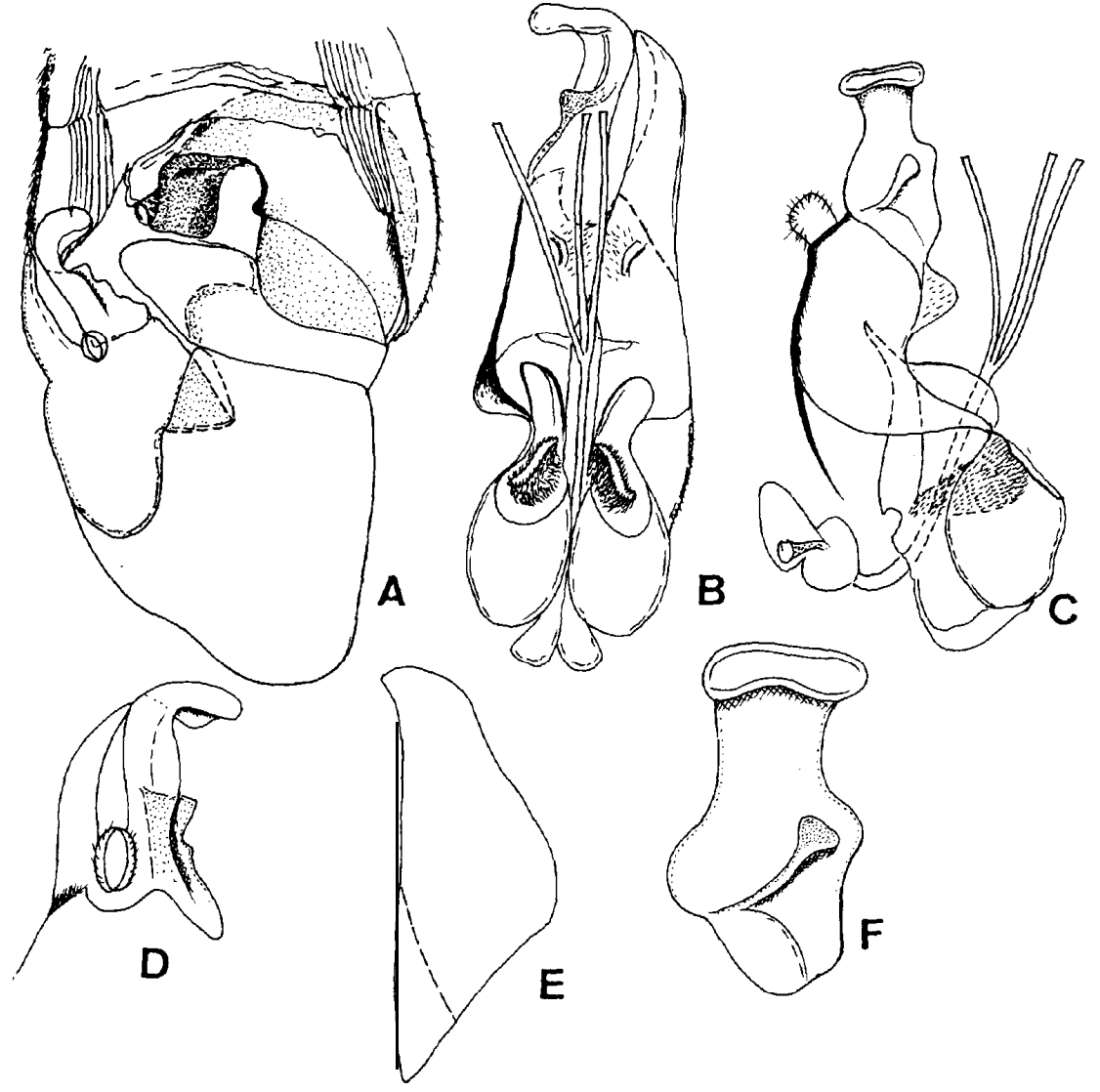

Fig. 111. Dorylomorpha yamagishii Marakote et Yano, sp. n. (male) : A. Abdomen, ventral ; B and C. genitalia (B. dorsal, C. lateral) ; D. surstyli, dorsal E. right surstylus, lateral ; F. left surstylus, lateral. 


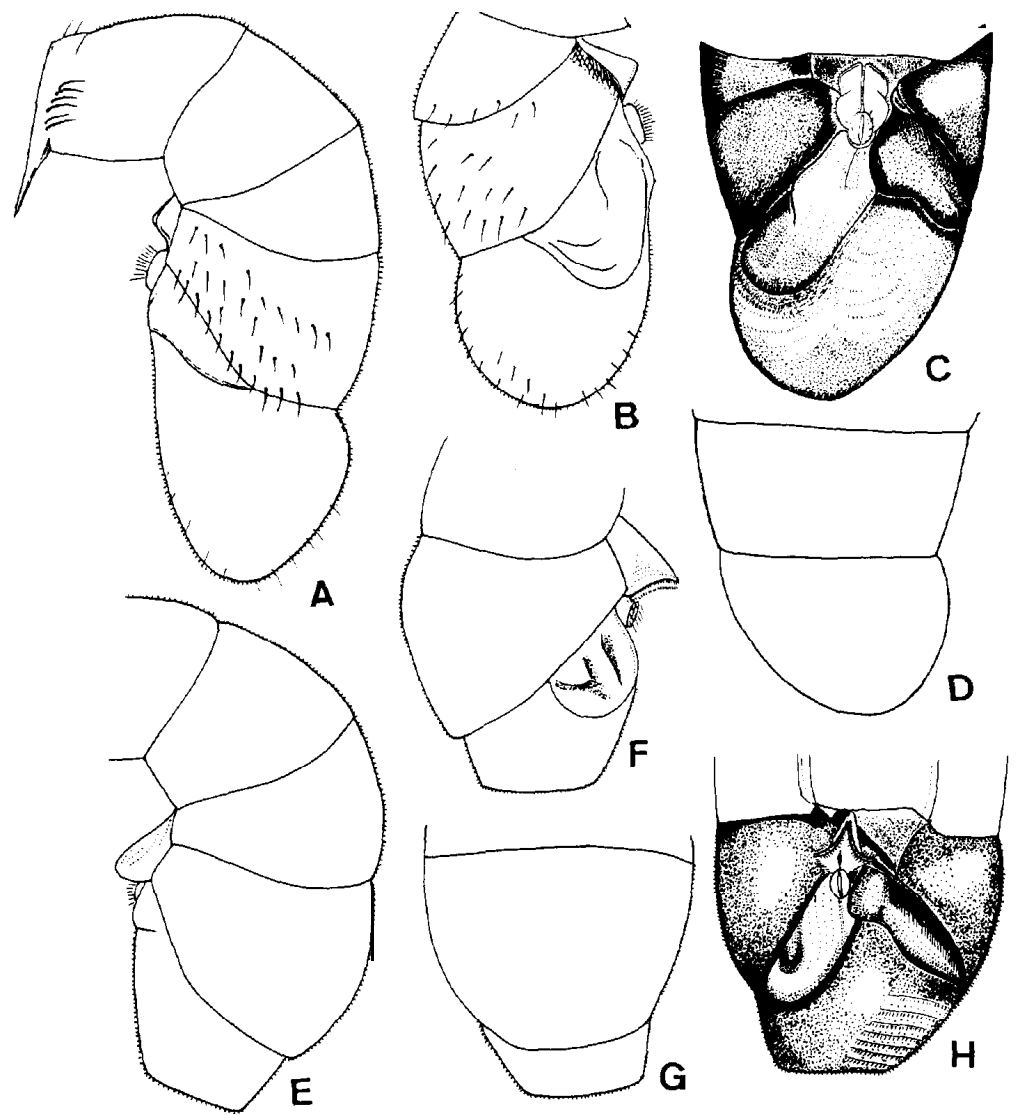

Fig. 112. A-D. Male abdominal terminalia of Dorylomorpha spinosa Albrecht ; E-H. male abdominal terminalia of D. rectitermina Morakote et Yano, sp. $\mathrm{n}$. 
品

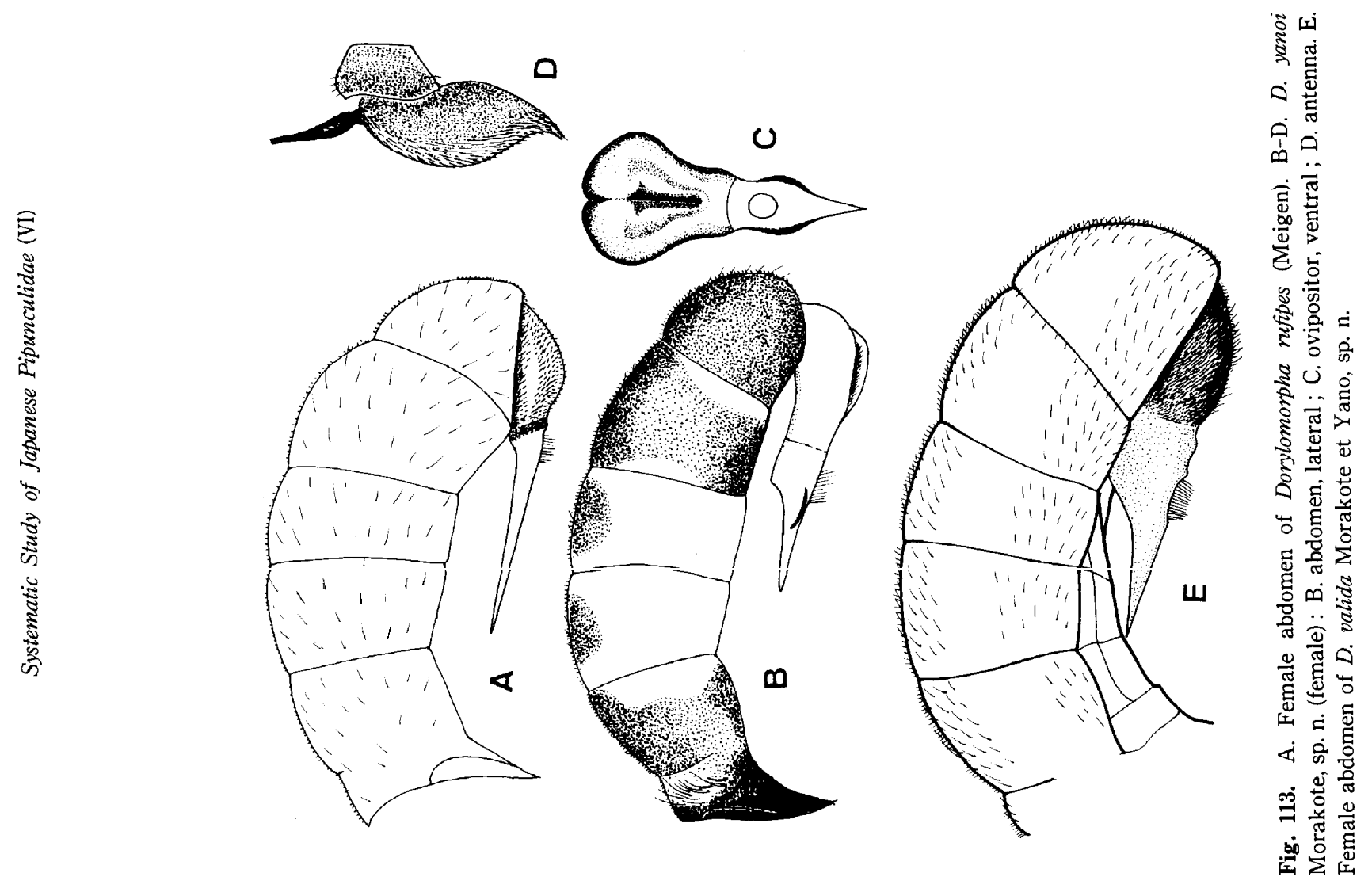




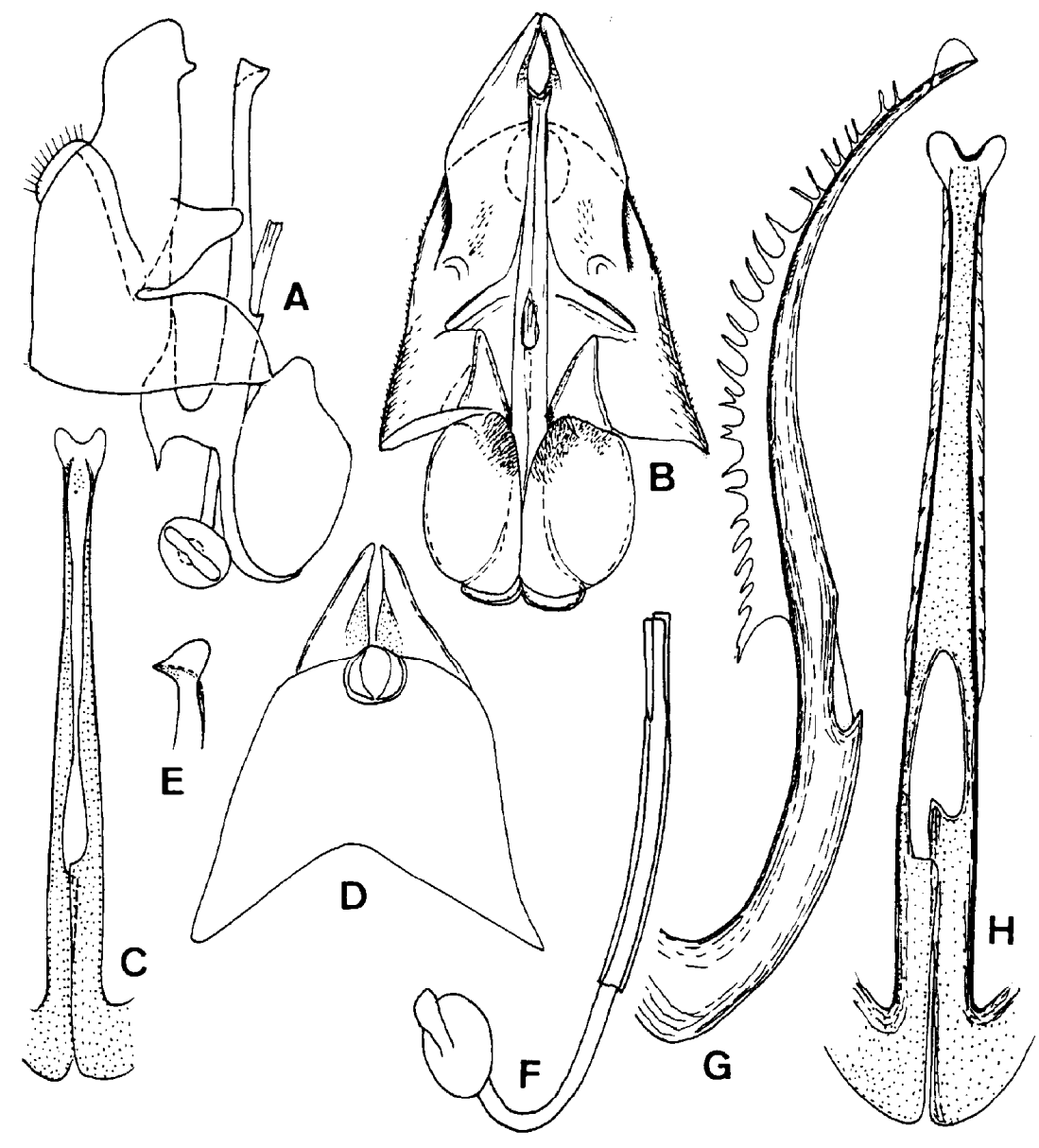

Fig. 114. A-E. Dorylomorpha imparata (Collin) (male) : A and B. Genitalia (A. lateral, B. dorsal) : C. aedeagal supporter, dorsal ; D. epandrium and surstyli, dorsal ; E. apex of aedeagal supporter, lateral. F-G. D. spinosa Morakote et Yano, sp. n. (male) : F. aedeagus; $\mathrm{G}$ and $\mathrm{H}$. aedeagal supporter (G. lateral, B, dorsal). 

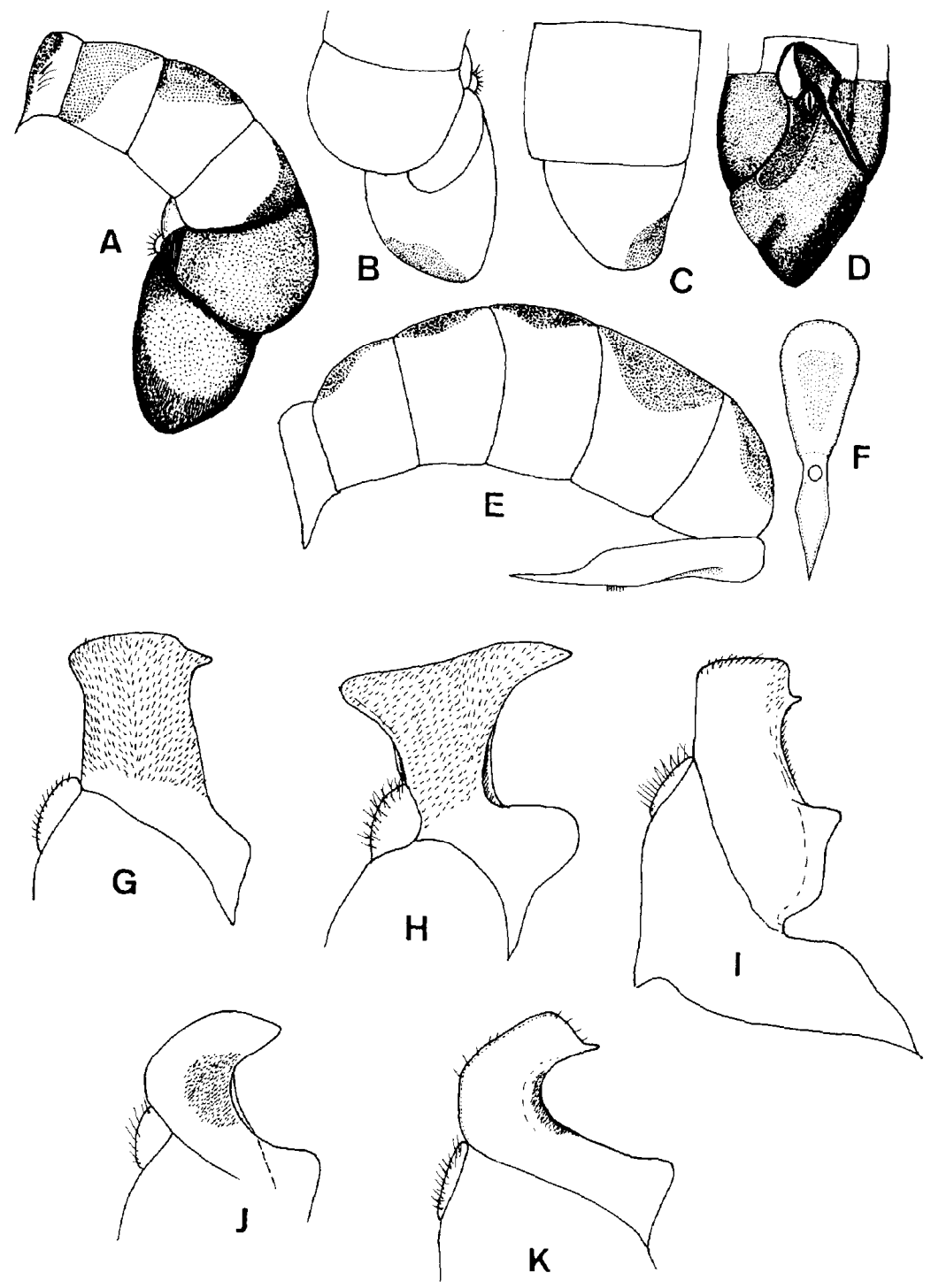

Fig. 115. A-F. Dorylomorpha yamagishii Morakote et Yano, sp. n. : A-D. Male abdominal terminalia ; E. female abdomen, lateral ; F. oviposiotor, ventral. G-H. Right surstylus of male genitalia of Dorylomorpha spp. : G. spinosa Albrecht ; H. rectitermina Morakote et Yano, sp. n. ; I. kurodakensis Morakote et Yano, sp. n. J. confusa (Verrall); K. extricata (Collin). 

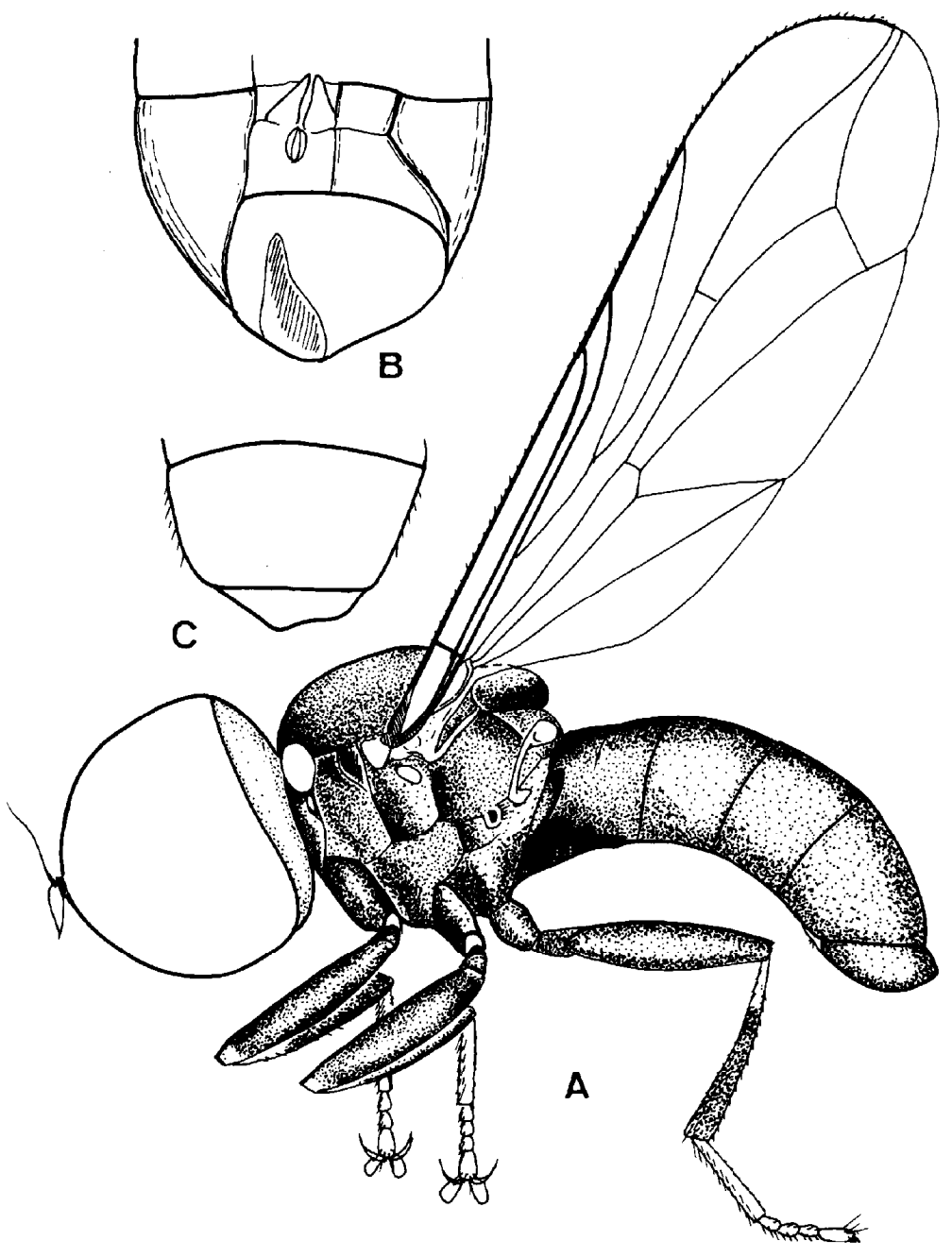

Fig. 116. Tomosvaryella epichalca (Perkins) (male) : A. Body ; B and C. abdominal terminalia (B. ventral, C. dorsal). 

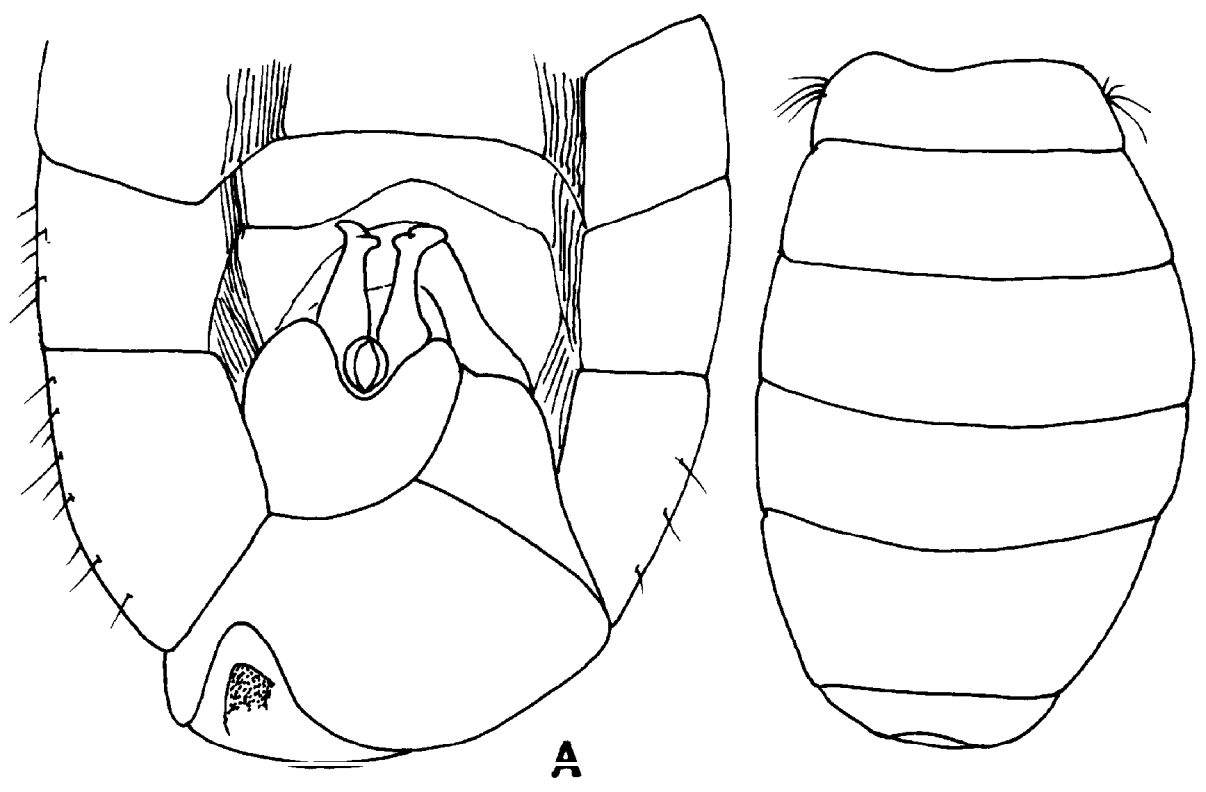

B
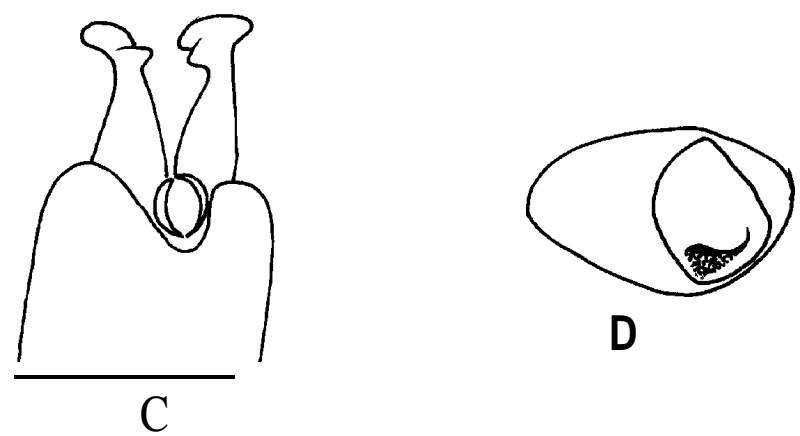

Fig. 117. Tomosvaryella caligata Hardy (male) : A. Abdominal terminalia, ventral ; B. abdomen, dorsal ; C. epandrium and surstyli, dorsal ; D. abdominal segment 8, behind. 

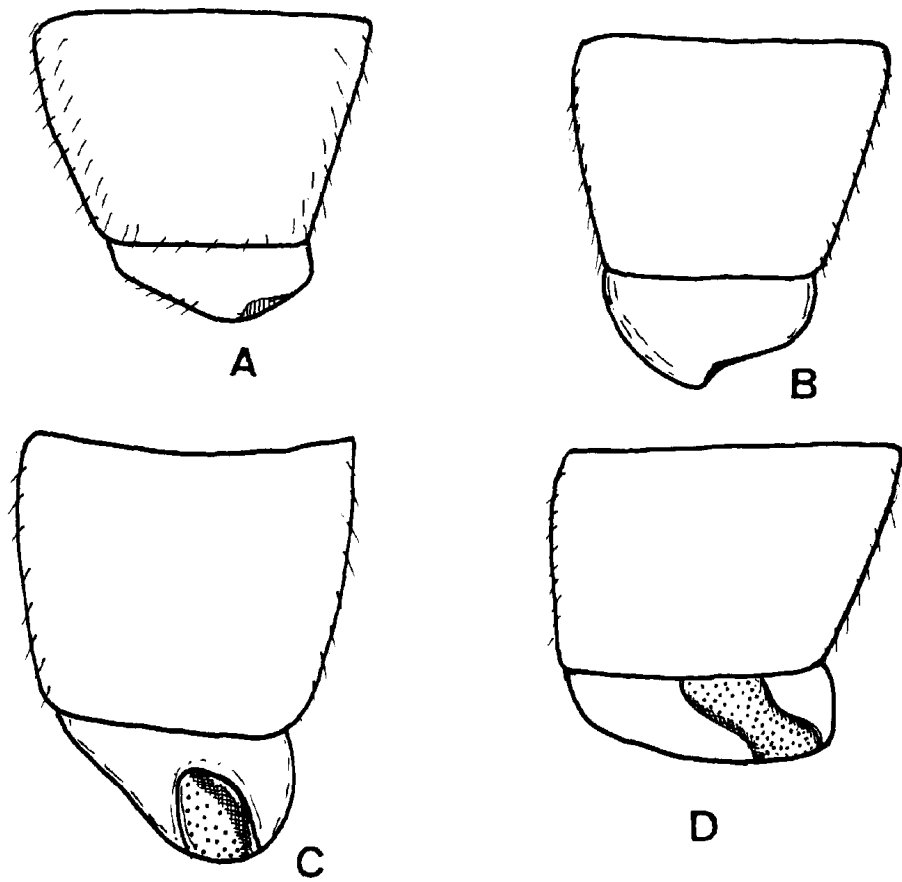

D
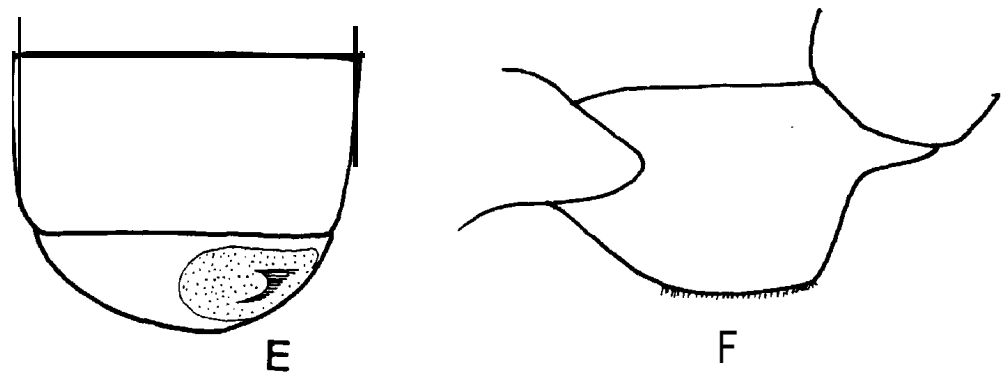

Fig. 118. A-E. Male abdominal terminalia (dorsal) of Tomosavaryella spp.: A. or yzaetora Koizumi ; B. inazumae (Koizumi) ; C. sylvatica (Meigen) ; D. coquiletti (Kertész); E. subvirescens (Loew) ; F. hind trochaters of T. subvirescens. 


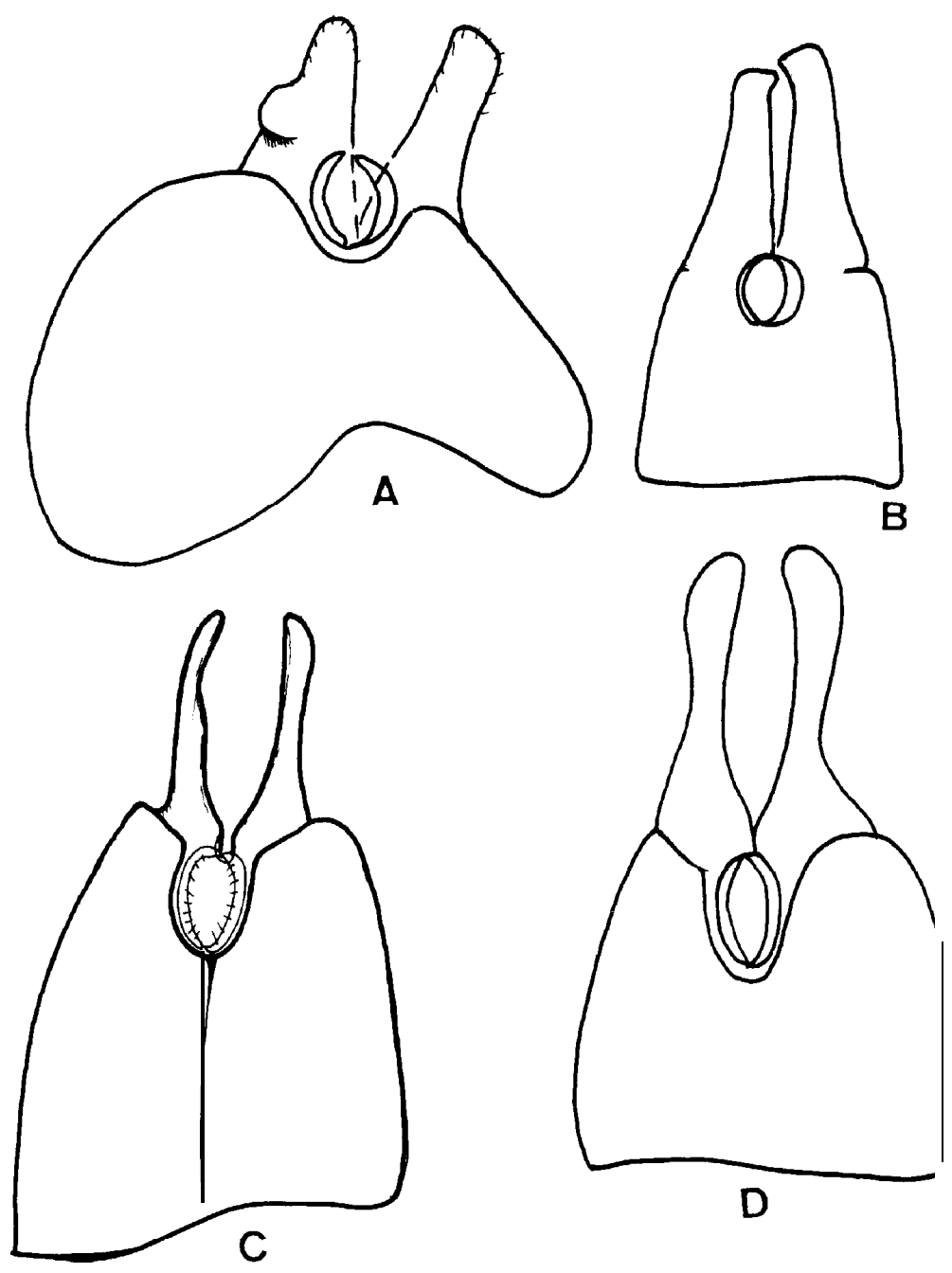

Fig. 119. Epandrium and surstyli of male genitalia of Tomosvaryella spp. : A. subvirescens (Loew) ; B. oryzaetora Koizumi ; C. coquiletti (Kertész); D. sylvatica (Meigen). 

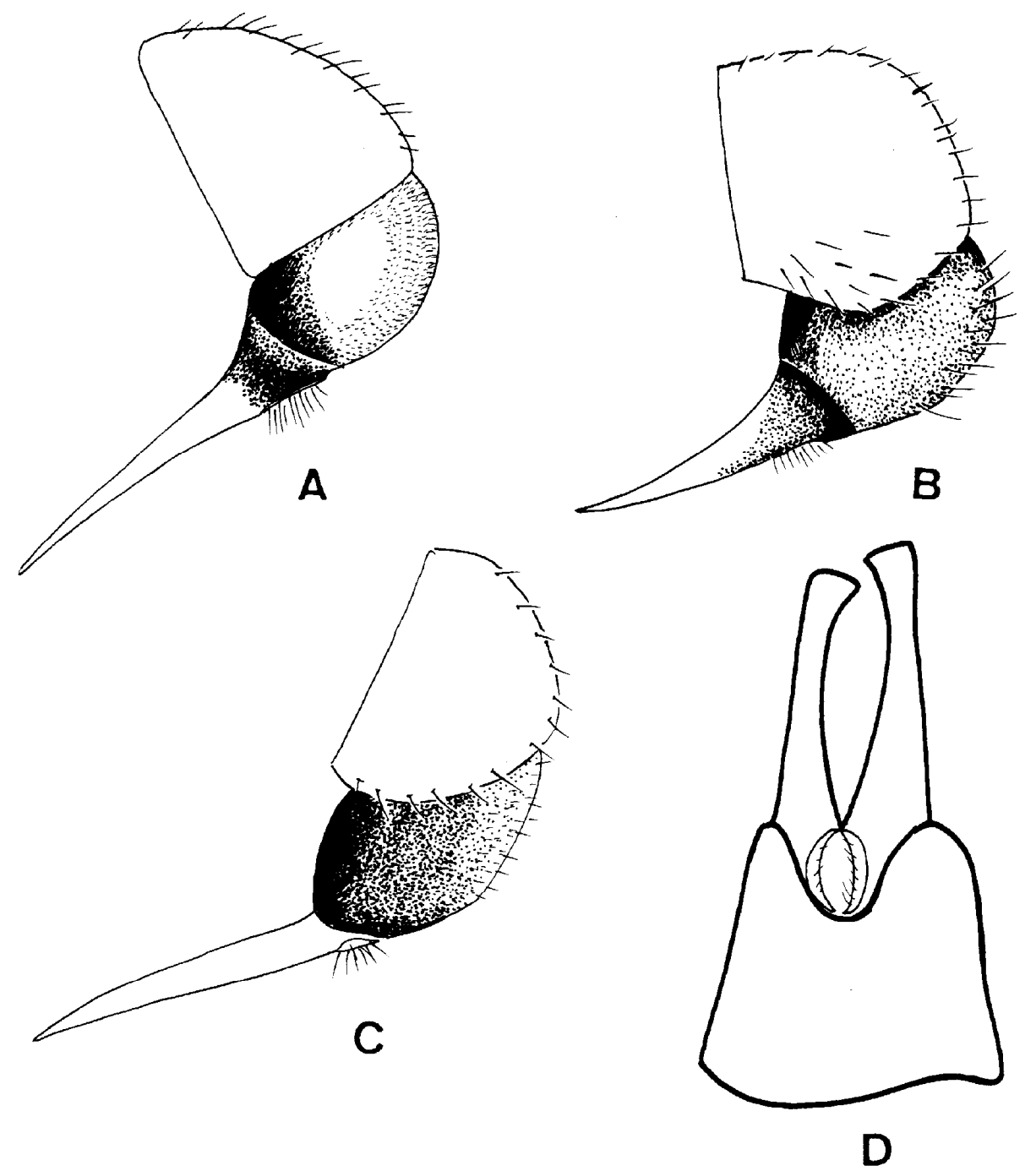

Fig. 120. A-C. Female ovipositor of Tomosvaryella spp. : A. sylvatica (Meigen); B. oryzaetora Koizumi ; C. inazumae (Koizumi) ; D. Epandrium and surstyli of male genitalia of T. inazumae, dorsal. 


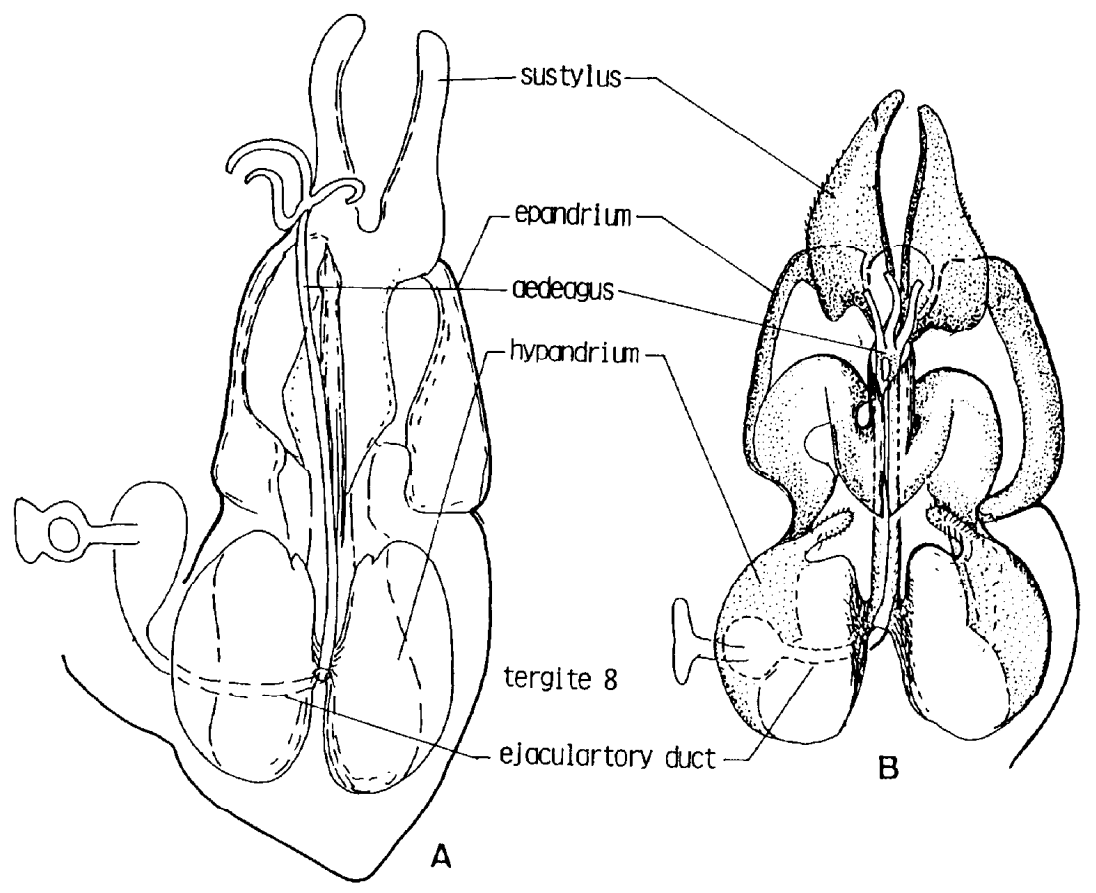

Fig. 121. Male genitalia of Tomosvaryella spp.: A. sylvatica (Meigen), dorsal ; B. epichalca (Perkins), dorsal. 